\title{
Fusarium mycotoxin enniatin B : Cytotoxic effects and changes in gene expression profile
}

\section{Jonsson, Martina}

2016-08

Jonsson , M , Jestoi , M , Anthoni , M , Welling , A , Loivamaa , I , Hallikainen , V , Kankainen , M , Lysoe , E , Koivisto , P \& Peltonen , K 2016 , ' Fusarium mycotoxin enniatin $B$ : Cytotoxic effects and changes in gene expression profile ' , Toxicology in Vitro , vol. 34 , pp. 309-320 . https://doi.org/10.1016/j.tiv.2016.04.017

http://hdl.handle.net/10138/224111

https://doi.org/10.1016/j.tiv.2016.04.017

publishedVersion

Downloaded from Helda, University of Helsinki institutional repository.

This is an electronic reprint of the original article.

This reprint may differ from the original in pagination and typographic detail.

Please cite the original version. 


\title{
Fusarium mycotoxin enniatin B: Cytotoxic effects and changes in gene expression profile
}

\author{
Martina Jonsson ${ }^{\mathrm{a}, *}$, Marika Jestoi ${ }^{\mathrm{b}}$, Minna Anthoni ${ }^{\mathrm{a}}$, Annikki Welling a , Iida Loivamaa ${ }^{\mathrm{a}}$, Ville Hallikainen ${ }^{\mathrm{c}}$, \\ Matti Kankainen ${ }^{\mathrm{d}}$, Erik Lysøe ${ }^{\mathrm{e}}$, Pertti Koivisto ${ }^{\mathrm{a}}$, Kimmo Peltonen ${ }^{\mathrm{a}, \mathrm{f}}$ \\ a Chemistry and Toxicology Research Unit, Finnish Food Safety Authority (Evira), Mustialankatu 3, FI-00790 Helsinki, Finland \\ b Product Safety Unit, Finnish Food Safety Authority (Evira), Mustialankatu 3, FI-00790 Helsinki, \\ c The Finnish Forest Research Institute, Rovaniemi Unit, P.O. Box 16, FI-96301 Rovaniemi, Finland \\ d Institute for Molecular Medicine Finland (FIMM), University of Helsinki, P.O. Box 20, FI-00014, Finland \\ e Plant Health and Biotechnology, Norwegian Institute of Bioeconomy, Høyskoleveien 7, NO -1430 Ås, Norway \\ ${ }^{\mathrm{f}}$ Finnish Safety and Chemicals Agency (Tukes), Opastinsilta 12 B, FI-00521 Helsinki, Finland
}

\section{A R T I C L E I N F O}

\section{Article history:}

Received 3 December 2015

Received in revised form 5 April 2016

Accepted 28 April 2016

Available online 6 May 2016

\section{Keywords:}

Enniatins

Mycotoxin

In vitro toxicity

Gene expression

Fusarium

\begin{abstract}
A B S T R A C T
The mycotoxin enniatin B, $a$ cyclic hexadepsipeptide produced by the plant pathogen Fusarium, is prevalent in grains and grain-based products in different geographical areas. Although enniatins have not been associated with toxic outbreaks, they have caused toxicity in vitro in several cell lines. In this study, the cytotoxic effects of enniatin B were assessed in relation to cellular energy metabolism, cell proliferation, and the induction of apoptosis in Balb 3T3 and HepG2 cells. The mechanism of toxicity was examined by means of whole genome expression profiling of exposed rat primary hepatocytes. Enniatin B altered cellular energy metabolism and reduced cell proliferation in Balb 3T3 and HepG2 cell lines. Furthermore, the proportion of apoptotic cell populations of Balb 3T3 cells slightly increased. On the other hand, enniatin B caused necrotic cell death in primary hepatocytes. Gene expression studies revealed the alteration of energy metabolism due to effects on mitochondrial organization and function and the assembly of complex I of the electron transport chain.
\end{abstract}

(c) 2016 Elsevier Ltd. All rights reserved.

\section{Introduction}

Enniatins (Enns), produced by the plant pathogenic fungi Fusarium, are common contaminants of grain in Northern Europe. In a 2001 Finnish survey on the mycotoxin content of grains, low levels of Enns were recurrently detected in $95-100 \%$ of the grain samples, with $18.3 \mathrm{mg} / \mathrm{kg}$ wheat being the highest concentration (Jestoi et al., 2004). Similar findings were reported in a Norwegian survey, with Enn contamination of up to $100 \%$ of grain samples and the highest enniatin B (EnnB) concentration being $790 \mu \mathrm{g} / \mathrm{kg}$ in wheat (Uhlig et al., 2006).

Enniatins are $\mathrm{N}$-methylated cyclic hexadepsipeptides, with 3 residues of D-2-hydroxyisovaleric acid alternating with 3 amino acid residues of valine, leucine, or isoleucine. The molecule has a disk form and is highly lipophilic (Jestoi, 2005, Desjardins, 2006). More than 20 isoforms of Enns exists and are synthetized by enniatin synthetase

Abbreviations: Bea, beauvericin; ELISA, enzyme-linked immunosorbent assay; Enn, enniatin; $\mathrm{ED}_{50}$, effective dose at which $50 \%$ of cells are affected; ETC, electron transport chain, a central part of cellular respiration.; $\mathrm{IC}_{50}$, inhibitory concentration at which $50 \%$ of enzyme activity is inhibited.; FDR, false discovery rate; GO, gene ontology, describes gene products in associated biological processes, cellular components and molecular functions.; o/n, over night; RT, room temperature.

* Corresponding author.

E-mail address: mkjonsson@gmail.com (M. Jonsson). enzymes by several Fusarium species, including F. avenaceum, F. poae, F. tricinctum, F. oxysporum, and F. sporotrichoides (Desjardins, 2006).

The clinically most important fusariatoxins, trichothecenes, zearalenone, and fumonisin, induce immunotoxicity, reproductive and developmental toxicity, and carcinogenicity in several animal species and humans (Desjardins, 2006, Jestoi, 2005). Enns, however, have not been associated with clinical outbreaks. A few in vivo studies have indicated a low level of or no toxicity. The $\mathrm{LD}_{50}$ of a commercial mixture of Enns (fusafungine) in mice was as high as $350 \mathrm{mg} / \mathrm{kg}$ b.w. (Berdy, 1980; EFSA Panel on Contaminants in the Food Chain (CONTAM), 2014). Furthermore, no adverse effects were detected in a 28-day subchronic feeding study on Wistar rats with a daily oral dose of $20.91 \mathrm{mg} / \mathrm{kg}$ b.w. EnnA (Manyes et al., 2014). As highly lipophilic compounds, Enns have been shown to bioaccumulate in eggs (Jestoi et al., 2009), and low levels were recovered from broiler meat, liver, and skin in a poultry feeding trial (CODA-CERVA, 2011-2012). Two metabolites have also been recovered from liver and serum samples of broilers, indicating a carry over to food and feed (Ivanova et al., 2014).

Although not very toxic in vivo, Enns have caused toxicity in vitro in several cell lines. The mode of action of Enns is thought to be related to the formation of cation-selective channels, which transport mono- and divalent cations across biological membranes, resulting in nonphysiological concentrations in the cell (Ivanov et al., 1973, Kamyar 
et al., 2004, EFSA Panel on Contaminants in the Food Chain (CONTAM), 2014). ATP-driven efflux pumps in intestinal epithelial cells form a barrier against xenobiotics by pumping them back to the gut lumen. Enns have been found to alter the efflux properties of two ATP-binding cassette $(A B C)$ transporters, $A B C B 1$ and $A B C G 2$, involved in multidrug resistance. Moreover, Enn exposure inhibited the efflux of pheophorbide ( $\mathrm{PhA}$ ) and rhodamin 123 in lung carcinoma A549 cells and leukemia HL60/Vinc cells, and led to the accumulation of these substrates in cells (Dornetshuber et al., 2009b). Enns may thereby influence the absorbance of other xenobiotics from the intestine.

Enns have been reported to cause a wide range of cytotoxic effects, including immunotoxicity (Gammelsrud et al., 2012), lysosomal alteration (Ivanova et al., 2012) and inhibition of enzyme activity. For example, Enns inhibited CoA:cholesterol acyltransferase (ACAT), involved in bile acid production (Tomoda et al.,1992) and calmodulin dependent $3^{\prime}, 5^{\prime}$-cyclic nucleotide phosphodiesterase (PDE) hydrolyzing the secondary messengers cyclic-AMP and cyclic-GMP (Mereish et al., 1990). Gammelsrud et al., reported alteration of the immune response due to reduced mitochondrial metabolic activity and lysosomal damage in RAW 267.4 macrophages (Gammelsrud et al., 2012). Furthermore, cell proliferation was altered due to cell cycle arrest, appearing in the G0/ G1 phase, and a concomitant decrease in cyclin D1 levels in exposed cells. EnnB also reduced the endocytosis capacity of macrophages exposed during the differentiation process of monocytes into macrophages (Ficheux et al., 2013). In a study by Ivanova et al., a dosedependent disruption of lysosomal membranes post exposure to EnnB in human colon adenocarcinoma Caco-2 cells was discovered using neutral red staining. A loss of mitochondrial membrane potential was also detected. Furthermore, EnnB caused cell death by increasing the level of necrotic cell populations of Caco-2 cells, rather than by induced apoptosis (Ivanova et al., 2012).

Dornetschuber et al., demonstrated that Enn cytotoxicity did not involve oxidative stress in HL-60 leukemia cells or cervix carcinoma KB-31 cells, or cause DNA damage in the form of DNA intercalation (Dornetshuber et al., 2009a).

Despite several toxicological studies on enniatins, the toxic impacts in different cell types and the exact mode of action remain unclear. In particular, the relevance of in vitro findings to toxic effects in vivo are difficult to define. Our study aimed to shed light on the toxic effects of EnnB on cellular energy metabolism, cell proliferation, and cell death in mouse embryo fibroblast Balb 3T3 cells and human hepatocellular carcinoma HepG2 cells. We also investigated the toxic mechanism of EnnB in rat primary hepatocytes, monitored at the gene expression level.

\section{Materials and methods}

\subsection{Chemicals}

\subsubsection{Mycotoxins}

The Fusarium mycotoxin enniatin B used in the toxicity assays was purchased from A.G. Scientific, Inc. (San Diego, California) and was isolated from Fusarium orthoceras var. enniatum. The purity was demonstrated to be $\geq 90-99 \%$ (HPLC analysis).

In gene expression studies, enniatin B isolated from Gnomonia errabunda was used (Sigma Aldrich, Saint Louis, USA), with a purity of 95\% (HPLC analysis).

\subsection{Bioassays}

\subsubsection{Cell maintenance and subcultivation}

The mouse embryo fibroblast cell line Balb 3T3, clone A31 (CCL-163, American Type Culture Collection, ATCC, USA) was used in all bioassays. The cells were cultured in DMEM (\#30-2002, ATCC) supplemented with $10 \%$ calf serum (\# 30-2031, ATCC, USA) and 2 mM L-glutamine (Sigma Chemical Co.), the antibiotics penicillin (100 IU/ml, Orion, Finland) and streptomycin ( $200 \mu \mathrm{g} / \mathrm{ml}$, Sigma-Aldrich, Finland). Human hepatocellular carcinoma HepG2 cells (HB-8065, American Type Culture Collection, ATCC, USA), also used in the bioassays, were cultured in MEM (\#30-2003, ATCC) and supplemented as above, however, using 10\% fetal bovine serum (FBS, \#30-2020, ATCC). The cells were maintained in $25 \mathrm{~cm}^{2}$ filter cap flasks (NunclonTM, Thermo Scientific) at $37^{\circ} \mathrm{C}$ in a humified incubator with $5 \% \mathrm{CO}_{2}$. Subcultivation for bioassays was performed twice a week at a ratio 1:10 in supplemented culture medium for $24 \mathrm{~h}$ (confluent growth) and dispersed on white, flat, clearbottom 96-well plates (ViewPlate-96TC, Perkin-Elmer) at a density of 10,000 cells per well for the ATP viability assay and 3000 cells per well on black 96-well plates (CellBIND surface, Corning, USA) for cell proliferation assay, in standard conditions $\mathrm{o} / \mathrm{n}$. Antibiotics were excluded to avoid synergistic effects with enniatin.

\subsubsection{Cell viability tests and cellular energy metabolism}

The lowest EnnB level tested $(1 \mu \mathrm{M} / 0.64 \mu \mathrm{g} / \mathrm{ml})$, equals to a level of $0.66 \mu \mathrm{g} / \mathrm{ml}$ in plasma, if water content is assumed to be $93 \%$ in plasma and $90 \%$ in growth media, respectively (Rhoades and Bell, 2009). These levels are approximately 10 times (9.04 times) higher than the EnnB plasma levels in a feeding trial study of pigs (plasma levels $0.073 \mu \mathrm{g} / \mathrm{ml}$ ) after an oral dose of $50 \mu \mathrm{g} / \mathrm{kg}$ b.w., equal to an EnnB level of $1 \mathrm{mg} / \mathrm{kg}$ feed (Devreese et al., 2013). Furthermore these values are about 10 times higher than the EFSA highest (mean) acute exposure estimate in Europe $(4.67 \mu \mathrm{g} / \mathrm{kg}$ b.w./day, toddlers)(EFSA Scientific Opinion, 2014). The lowest tested level ( $1 \mu \mathrm{M}$ EnnB $)$ in our study refers to nearly a 100 times higher exposure level. However, as the levels of Enns in cereals show a high annual variation (from traces to $18.3 \mathrm{mg} / \mathrm{kg}$ wheat, Finland, Jestoi et al., 2004) this lowest exposure level may be relevant in the worst case in vivo situations.

Cell membrane integrity was tested using the Toxilight bioluminescent assay (LT07-217, Lonza, Rockland, USA), which measures the release of the enzyme Adenylate kinase (AK) through damaged plasma membranes of cells. The effect of EnnB on cellular energy metabolism (ATP production) was assessed with ViaLight Plus Bioassay (LT07-221, Lonza, Rockland, USA). The cells were exposed to different toxin concentrations in growth medium ( $100 \mu \mathrm{l} /$ well) ranging from $1.5 \mu \mathrm{M}$ to $100 \mu \mathrm{M}$ EnnB for $24 \mathrm{~h}$. Both experiments were performed according to manufacturer's protocols, using the same cell samples. AK release was measured from the growth media post EnnB exposure and ATP levels from the disrupted cell layers. The luminescence of the samples was measured using a Victor ${ }^{3}$ Multilabel Plate Reader 1420 (Perkin Elmer, Belgium). The emitted light intensity is linearly related to the released AK concentration and to ATP concentration in cells.

\subsubsection{Cell proliferation assay (BrdU ELISA)}

The effects of enniatin B exposure on the proliferation (DNA synthesis) of Balb 3T3 and HepG2 cells was examined using a chemiluminescent cell proliferation ELISA immunoassay (Ref 1166915001, Roche Diagnostics GmbH, Mannheim, Germany). The cells were exposed to EnnB concentrations ranging from 3 to $12 \mu \mathrm{M}$ in growth medium and incubated as above for $24 \mathrm{~h}$. The experiment was performed according to manufacturer's instructions. Luminescence was measured with a Victor $^{3}$ Multilabel Plate Reader 1420 (Perkin Elmer, Belgium). The chemiluminescence (rlu/s), produced by luminol, correlates with the level of DNA synthesis in the cell.

\subsection{Apoptosis}

To study changes in the quantity of pro-apoptotic cell populations by flow cytometry, the Annexin V-FITC/PI double-staining kit (Cat \# K10125 , Biovision) was used. Balb $3 \mathrm{~T} 3$ cells were cultured in standard conditions for 24 h on 6 well-plates (Cat. No. 140685, Nunclon surface, Nunc ${ }^{\circledR}$ ) at 450,000 cells/well. The growth medium was removed and the cells were exposed to three different toxin concentrations: $11 \mu \mathrm{M}$, $22.5 \mu \mathrm{M}$, and $45 \mu \mathrm{M}$ EnnB for $24 \mathrm{~h}$ and $48 \mathrm{~h}$. Camptothesin $(10 \mu \mathrm{M}$ and 
$20 \mu \mathrm{M}$ ) was used as a positive control. Unexposed cells were used as negative controls and for flow cytometer calibration: unstained cells, cells stained with only PI or Annexin V-FITC, and one control with cells stained with both dyes. The cells were detached by adding $2 \mathrm{ml}$ or $1 \mathrm{ml}$ of $0.25 \%$ trypsin - $0.53 \mathrm{mM}$ EDTA in HBSS and collected by centrifugation (Eppendorf 5810R) at $1700 \mathrm{rpm}$ for $5 \mathrm{~min}$ at $+4{ }^{\circ} \mathrm{C}$. The cells were resuspended in $500 \mu \mathrm{l} 1 \times$ binding buffer following the addition of $5 \mu \mathrm{l}$ of both Annexin V-FITC and propidium iodide (PI) stains. The cells were incubated 5 min in RT in the dark and immediately analyzed by flow cytometry (BD FACSAria II, Becton, Dickinson and Company). For each experiment, 10,000 events were acquired, single cells were gated, and FITC and PI fluorescence were measured using $530 \mathrm{~nm}$ and $617 \mathrm{~nm}$ band-pass filters. The data were analyzed using BD FACSDiva software for early apoptotic/necrotic populations.

\subsection{Gene expression studies}

\subsubsection{Rat primary hepatocyte cell cultivation}

Primary hepatocytes were chosen for this study because they are considered to better correspond to in vivo studies than immortalized cell lines. However, the lifespan of cryopreserved primary hepatocytes is rather short, being only $12-24 \mathrm{~h}$, including a $4-8 \mathrm{~h}$ period of attachment to the culture plate surface. This limited the duration of the experiments.

Cryopreserved rat primary hepatocytes (RTCP 10, Gibco, Life Technologies, USA), used in the gene expression studies, were maintained and cultured according to the manufacturer's instructions, using ready-to-use cryopreserved hepatocyte recovery medium (CHRM, APSciences Inc., USA) and cryopreserved hepatocyte plating medium (CHPM, APSciences Inc., USA). Only cell suspensions with more than $\geq 79 \%$ viability were used. Cells were diluted and plated at a density of 2000 viable cells per well on collagen-coated 6 -well plates (Thermo Scientific, NY, USA) and incubated at $37^{\circ} \mathrm{C}$ in a humified incubator with $5 \%$ $\mathrm{CO}_{2} \mathrm{o} / \mathrm{n}$ to allow the cells to attach to the collagen surface of the plates.

\subsubsection{Microarray method}

The cells were exposed for 1 and $4 \mathrm{~h}$ in standard conditions to $0 \mu \mathrm{M}$, $1 \mu \mathrm{M}, 10 \mu \mathrm{M}$, and $20 \mu \mathrm{M}$ EnnB in maintenance medium (William's E medium, without phenol red (WEM)), supplemented with $4 \%$ cocktail B (Gibco, Life Technologies, UK) respectively, representing a negative control, a low toxin level, the $\mathrm{EC}_{50}$, and a high level of toxin. RNA was isolated using the RNeasy Plus Mini Kit (Cat. No. 74134, Qiagen). The growth medium was removed and $300 \mu \mathrm{l}$ of lysis buffer RLT, containing $\beta$ mercaptoethanol, was added to each well. The cells were detached by scraping and the cell suspensions were homogenized using QIAshredder columns (Cat. No. 79654, Qiagen). RNA isolation was performed according to manufacturer's instructions. RNA samples were immediately placed on ice and stored at $-80^{\circ} \mathrm{C}$.

Genome-wide expression analysis of the exposed rat primary hepatocyte samples was carried out using rat total genome RaGene 2.0 ST expression arrays (Ref 520784, Affymetrix, USA) and the Affymetrix standard protocol. The expression analysis was performed by the Functional Genomics Unit at the University of Helsinki in April 2013. The labeling and hybridization were carried out according to the manufacturer's instructions with minor modifications, using the Ambion WT Expression Kit for Affymetrix GeneChip Whole Transcript Expression Arrays (Part Number 4425209 Rev. C 09/2009, Applied Biosystems). The probe-group intensity data were collected using a GeneChip ${ }^{\circledR}$ Scanner (Affymetrix, USA). The data were collected from 4 independent experiments.

\subsection{3. qPCR method}

Seven genes were chosen on the basis of the microarray results for further expression analysis by quantitative real-time PCR (RT-qPCR). Rat primary hepatocytes were exposed to $0 \mu \mathrm{M}$ and $10 \mu \mathrm{M}$ EnnB in growth medium (representing a negative control and the EC50) for
$1 \mathrm{~h}$ and $4 \mathrm{~h}$ in standard conditions. RNA was isolated as in the microarray experiments using the RNeasy Plus Mini Kit (Cat. No. 74134, Qiagen). The cDNA synthesis was performed with the ReadyScriptTM cDNA Synthesis Mix (Sigma-Aldrich) according to manufacturer's instructions. Predesigned KiCqStart SYBR green primers (Sigma-Aldrich) specific for rat genes were used in the analysis (Table 5).

Quantitative real-time PCR was conducted using $100 \mathrm{ng}$ of cDNA as a template, KiCqStart ${ }^{\circledR}$ SYBR Green qPCR Ready MIX for BioRad CFX (Sigma-Aldrich, KCQS00), and $450 \mathrm{nM}$ of each primer per reaction. The PCR cycles for BioRad CFX96 were as follows: initial denaturation at $95^{\circ} \mathrm{C}$ for $30 \mathrm{~s}$, followed by 40 cycles of $95^{\circ} \mathrm{C}$ for $15 \mathrm{~s}, 58{ }^{\circ} \mathrm{C}$ for $30 \mathrm{~s}$, and $72{ }^{\circ} \mathrm{C}$ for $15 \mathrm{~s}$. The rat SDHA gene (Table 5) served as reference gene. Three technical repeats were used for each gene. The efficiency of each reaction was analyzed, and as it was slightly different between the genes, relative quantification was analyzed by the Pfaffl method (Bio-rad, 2006). The experiment was performed twice.

\subsection{Statistics}

\subsubsection{Statistical analysis in cell viability and cell proliferation studies}

A three-parameter Weibull function with parameterization 2 was used in the modeling of the toxic effects on ATP production and cell proliferation of Balb 3T3 cells. For HepG2 cells, a three-parameter Weibull function with parameterization 1 was used in the modeling of toxic responses on ATP production and a four-parameter Weibull function with parameterization 1 was used for the cell proliferation model. The best model function was selected based on the minimum values of residual variance and by comparing the alternative models using ANOVA tests (ANOVA function in $\mathrm{R}$ ). The models were fitted using the $\mathrm{R}$ package 'drc' (Ritz and Streibig, 2005).

\subsubsection{Statistical analysis in cell death studies (apoptosis)}

The statistical analyses were conducted using GraphPad Prism 5.0 software. A two-tailed nonparametric Mann-Whitney $U$ test or Kruskal-Wallis test together with Dunn's Multiple Comparison Test was used to assess the significance of the differences between untreated and treated samples in the apoptotic cell death data.

\subsubsection{Statistical analysis of gene expression}

2.5.3.1. Statistical analysis in microarray experiments. The gene expression data were pre-processed and $\log _{2}$ transformed using the R library RMA (Irizarry et al., 2003) and EnsEMBL gene custom probe mappings (version 17.0.0 based on EnsEMBL. rat genome build 70) (Dai et al., 2005). To list differentially expressed probe sets between samples, a moderated paired $t$-test (pairing carried over individual rat samples) was conducted using the R library "limma” (Smyth, 2004). Differential expression $p$-values were false discovery rates (FDR) adjusted using the q-value Bioconductor package (Storey and Tibshirani, 2003). Probes with a q-value $\leq 0.05$ were accepted as significantly different between two conditions.

2.5.3.1.1. Enrichment analysis of microarray data. Gene ontology (GO) enrichment analysis of the transcriptome was performed using Blast2GO software (Conesa et al., 2005). Lists of differentially expressed genes (with absolute $\log _{2}$-fold change $\geq \pm 1$, q-value $\leq 0.05$ ) were analyzed with Fisher's exact test together with false discovery rate (FDR) correction (Benjamini-Hochberg correction) to find enriched gene ontology categories in up- and downregulated genes. The enrichment analysis was run with default values. A two-tailed test was used to discover over- and under-representation of probe sets in functional categories and a false discovery rate (FDR) value of 0.01 was used as a cutoff value for significance.

2.5.3.1.2. Cluster Analysis of Microarray Data. Cluster analysis was conducted on all probe sets with statistically significant changes in expression compared to the negative control sample of the series (i.e. $1 \mathrm{~h}, 0 \mu \mathrm{M}$ EnnB and 4 h, $0 \mu \mathrm{M}$ EnnB samples), as well as on probe sets 
that were part of the gene ontology term mitochondrial organization (GO: 0007005) present on the chip, including 37 probe sets that were enriched. The cluster analysis was performed using the TMeV Multiple Experiment Viewer 4.9.0. program (Saeed et al., 2003). In all analyses, hierarchical clustering was performed using the Euclidean distance.

\section{Results}

Mouse fibroblast Balb 3T3 cells were chosen for testing the different cytotoxic effects of EnnB, as this cell line is considered to be very sensitive to the adverse effects of xenobiotics. HepG2 cells were used to study possible hepatotoxic effects and enable the comparison of toxic effects between different cell lines. EnnB clearly reduced the viability of both Balb 3T3 cells and HepG2 cells, altering cell proliferation and ATP production at relatively low concentrations. However, light microscopy studies did not reveal changes in typical cell morphology or cell death in the studied concentration ranges in Balb 3T3 or HepG2 cells (Fig. 1A and $B$ ). This observation is in line with the results of Toxilight cytotoxicity assay (Lonza), measuring adenylate kinase (AK) leakage through the plasma membrane in damaged cells, as no leakage of AK from EnnB exposed Balb 3T3 cells to the growth media could be detected (Fig 2). Furthermore, flowcytometric studies performed to study apoptotic effects of EnnB (Section 3.3 Apoptosis) revealed the majority of the cells to be intact post a $24 \mathrm{~h}$ exposure to EnnB $(11 \mu \mathrm{M}, 22 \mu \mathrm{M}, 45 \mu \mathrm{M})$. The ratio of intact cells vs. damaged cells was comparable to the negative control cells, as the proportion of intact cells in the negative control samples were $86 \pm 15 \%$ and in EnnB exposed cells $96.6 \pm 0.25 \%(11 \mu \mathrm{M})$, $91.0 \pm 4.9 \%(22 \mu \mathrm{M})$ and $84.3 \pm 12 \%(45 \mu \mathrm{M})$, respectively. In contrast to the cell lines, the effect of EnnB on rat primary hepatocyte morphology was prominent with an exposure of only $4-5 \mathrm{~h}$ to $10 \mu \mathrm{M}$ EnnB,

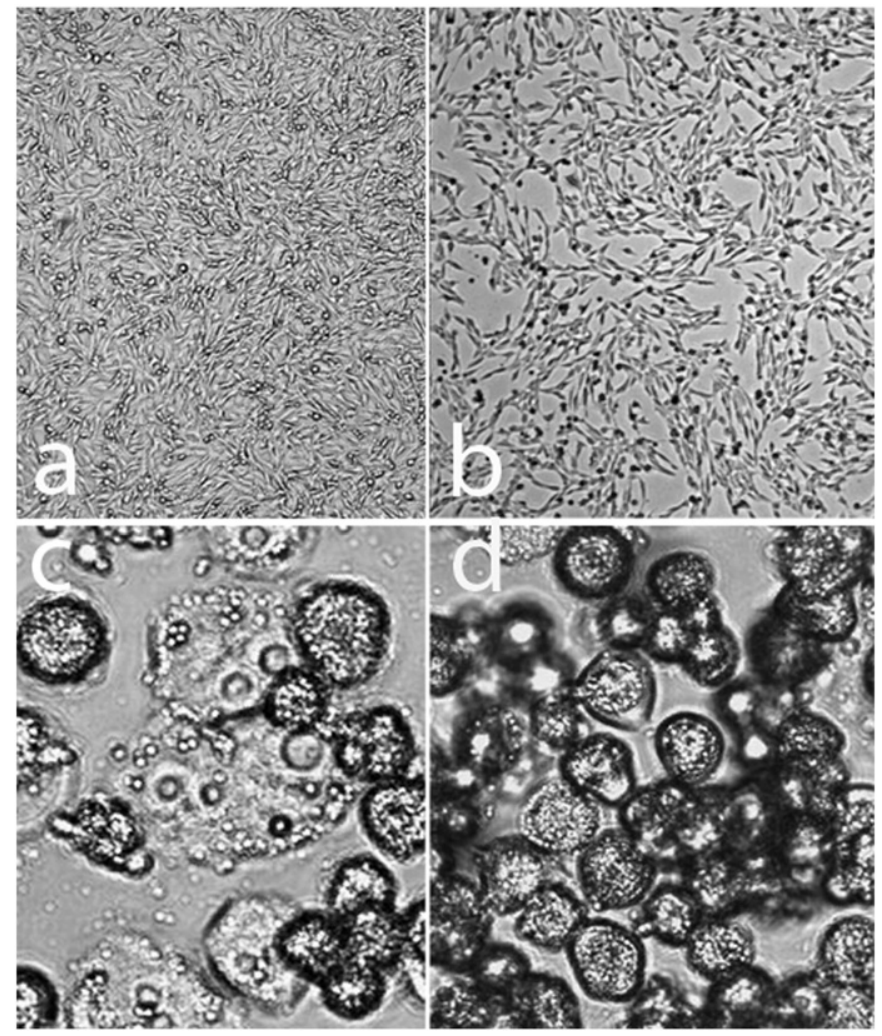

Fig 1. (A) Light microscopy images of mouse Balb $3 \mathrm{~T} 3$ cells (negative control) and cells exposed to $22 \mu \mathrm{M}$ EnnB for $24 \mathrm{~h}$ (B). Exposed cells remain intact, however stop proliferating, giving rise to a less dense cell culture compared to the negative control. (C) Images of untreated rat primary hepatocytes (negative control) and primary hepatocytes exposed to $10 \mu \mathrm{M}$ EnnB for $4 \mathrm{~h}$ (D). Exposed cells round up, detach from culture plate surface and die. $(20 \times$ objective, EVOS $®$ XL Imaging System, Thermo Fisher Scientific).

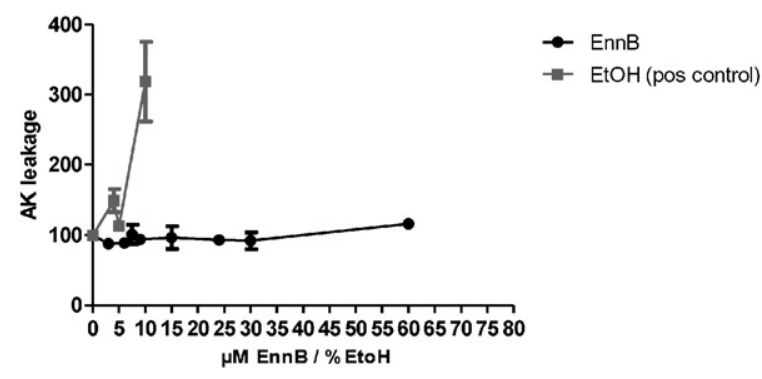

Fig 2. Relative leakage of adenylate kinase (AK) enzyme through the plasma membrane of Balb $3 \mathrm{~T} 3$ cells was not detected in any tested EnnB levels ( $3 \mu \mathrm{M}-60 \mu \mathrm{M})$, post a $24 \mathrm{~h}$ exposure (black line). Ethanol was used as a positive control for cell damage (grey line). Each data point represents the result of three independent experiments.

causing the majority of the primary hepatocytes to round up and detach from the plate surface and release cell contents in a necrotic manner (Fig. 1C and D).

\subsection{Cell energy metabolism (ATP production)}

The effect of EnnB on cellular energy metabolism was determined by measuring ATP levels in cells using the ViaLight Plus Bioassay (Lonza). A 24-h EnnB exposure of Balb 3T3 cells reduced intracellular ATP levels in a steeply declining and dose-dependent manner, with an $\mathrm{ED}_{50}$ value of $8.4 \pm 0.76 \mu \mathrm{M}$ EnnB (Fig. 3 ). EnnB concentrations below $3 \mu \mathrm{M}$ had no influence on Balb 3T3 cells. The effect on HepG2 cells elicited a similar pattern, and the estimated $\mathrm{ED}_{50}$ value $(2.9 \pm 0.7 \mu \mathrm{M})$ was somewhat lower than for Balb 3T3 cells, suggesting that HepG2 cells might be more sensitive to EnnB.

\subsection{Cell proliferation}

Exposure to EnnB altered DNA synthesis, measured by BrdU incorporation into the DNA of dividing cells (BrdU Elisa, Roche). DNA synthesis markedly declined in both cell lines (Balb 3T3 and HepG2) after EnnB exposure. The toxic effect could be detected within a narrow concentration range, with an estimated $\mathrm{ED}_{50}$ value of $4.24 \pm 0.06 \mu \mathrm{M}$ in Balb 3T3 cells and $0.50 \pm 0.09 \mu \mathrm{M}$ in HepG2 cells. Concentrations under $3.5 \mu \mathrm{M}$ showed no inhibition in Balb 3T3 cells (Fig. 4).

\subsection{Apoptosis}

Induction of apoptosis was studied by flow cytometric measurements of early apoptotic and late apoptotic/necrotic cell populations and intact cells using Annexin V-FITC/PI staining. Mouse Balb 3T3 cells were exposed to three EnnB concentrations $(11 \mu \mathrm{M}, 22 \mu \mathrm{M}$, and $45 \mu \mathrm{M}$ ) for $24 \mathrm{~h}$ and $48 \mathrm{~h}$. Camptothesin concentrations of $10 \mu \mathrm{M}$ and $20 \mu \mathrm{M}$ were used as positive controls and cells receiving fresh growth media as a negative control. Treatment for $24 \mathrm{~h}$ slightly increased the number of early apoptotic cells in a dose-dependent manner, from $0.3 \%$ of negative control cells to $1.25 \%$ at a dose of $11 \mu \mathrm{M}\left(\approx \mathrm{ED}_{50}\right)$ and to $2.5 \%$ and $4.4 \%$ at high doses of $22 \mu \mathrm{M}$ and $45 \mu \mathrm{M}$ EnnB, respectively. The effect was comparable to the positive control, camptothesin, with an increase in the proportion of early apoptotic cells to 1.85\% and 3.0\% at doses of $10 \mu \mathrm{M}$ and $20 \mu \mathrm{M}$, respectively (Fig. 5). The proportion of late apoptotic/necrotic cells also displayed a rising trend with an increase in EnnB levels, although the trend was not statistically significant. The 48-h EnnB exposure gave rise to similar findings, with a statistically significant increase in the early apoptotic cell population from $0.0 \%$ to 3.6\% at the highest EnnB dose of $45 \mu \mathrm{M}$ (data not shown).

\subsection{Gene expression studies}

The overall gene expression of rat primary hepatocytes treated with a low dose $(1 \mu \mathrm{M})$ of EnnB for $4 \mathrm{~h}$ did not significantly differ from the 

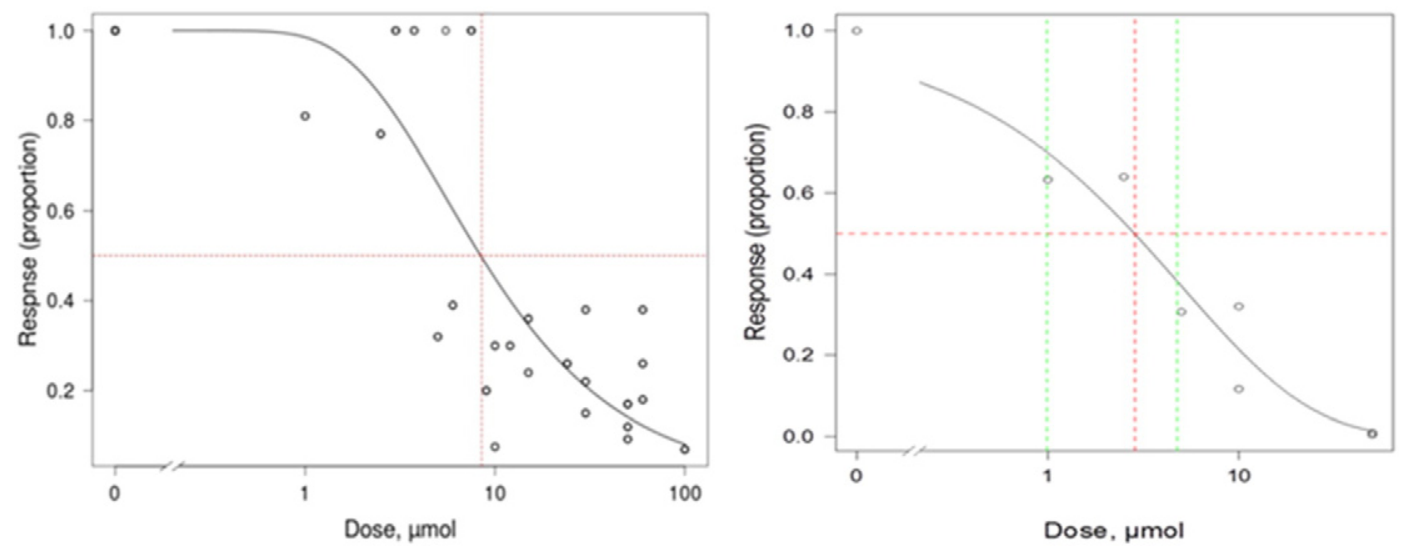

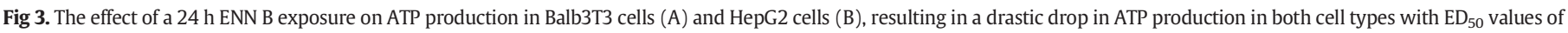
$8.41 \mu \mathrm{M} \pm 0.76 \mu \mathrm{M}$ ENN B in Balb $3 \mathrm{~T} 3$ cells and $2.87 \pm 0.77 \mu \mathrm{M}$ ENN B in HepG2 cells.

expression of untreated cells. However, a 4-h exposure to $10 \mu \mathrm{M}$ and $20 \mu \mathrm{M}$ EnnB resulted in an altered gene expression profile of the rat genome. The 10- $\mu \mathrm{M}$ dose compromised the normal expression levels most, with $4.8 \%$ (985 genes) of the genes in the rat total genome array significantly downregulated and only $0.89 \%$ (179 genes) significantly upregulated (Fig. 6). A limit of the $\log _{2}$ fold change (a $100 \%$ change in expression) and a q value $\leq 0.05$ was considered significant.

Enrichment analysis (Fisher's exact test) of downregulated genes suggested the most enriched gene ontology (GO) terms to include mainly catabolic and metabolic processes and the GO term mitochondrion organization (Table 1 ).

The 37 downregulated genes forming part of the GO term mitochondrial organization are listed in Table 2. Interestingly, downregulated genes were also modestly enriched in genes associated with apoptotic processes (apoptotic mitochondrial changes, FDR $\leq 3.3 \mathrm{E}-01$ ), cell signal transduction (TOR signaling, FDR $\leq 1.78 \mathrm{E}-01$, ERBB signaling pathway, $\mathrm{FDR} \leq 1.85 \mathrm{E}-01$, MAPK activated stress cascade, FDR $\leq 3.9 \mathrm{E}-01$ ), and the iron-sulfur cluster assembly (FDR $\leq 3.0 \mathrm{E}-01)$.

Enrichment analysis revealed no functional categories with significant FDR values among upregulated genes. Nonetheless, the most over-represented GO terms among upregulated genes were protein kinase $C$-activating $G$-protein coupled receptor signaling pathway (FDR $\leq 2.3 \mathrm{E}-01$ ), negative regulation of hexokinase activity (FDR $\leq 9.3 \mathrm{E}-01)$, negative regulation of glucokinase activity (FDR $\leq 9.3 \mathrm{E}-01$ ), and chromatin organization (FDR $\leq 9.3 \mathrm{E}-01$, Table 1). G-protein-coupled receptor signaling increased cytoplasmic $\mathrm{Ca}^{2+}$ levels in the cytosol. Cytosolic $\mathrm{Ca}^{2+}$ is involved in several signaling pathways in the cell, such as the calmodulin signal transduction pathway, which is important in carbohydrate metabolism and apoptosis
(Mereish et al., 1990, Kamyar et al., 2004). Hexokinases phosphorylate hexoses and are involved in glycolysis and glycogen production, and negative regulation could cause energy deprivation in the cell (Wilson, 2003).

Since our study revealed a drastic decrease in ATP production in Blab 3T3 and HepG2 cells post-exposure to EnnB and there was enrichment among the downregulated genes of the GO term mitochondrion organization (GO: 0007005, FDR $\leq 8.4 \mathrm{E}-03$ ) in rat primary cells, this group of genes was further analyzed. The GO term included more than 300 genes involved in mitochondrial assembly, the arrangement of constituent parts, or disassembly (The European Bioinformatics Institute, the EBI, 2015). Hierarchical clustering analysis of these genes was conducted and revealed 3 distinctly clustered gene sets, 2 of which consisted of downregulated genes and 1 of upregulated genes (Fig. 7).

Among the downregulated clusters, three were members of the Ndufs family of genes (Ndufs1, Ndufs4 and Ndufs8). The Ndufs genes are subunits of complex I the first enzyme in the electron transport chain in the mitochondrial inner membrane, leading to ATP production. The microarray data revealed an expression trend of downregulation among several of the Ndufs family of genes, although Ndufs 4 is the only gene that reached the (self-set) threshold for statistical significance (Fig. 8). Ndufs proteins are NADH dehydrogenase Fe-S proteins, and form parts of the iron-sulfur fragment of complex I (Genecards, 2015). In addition to the clustering of the Ndufs family, three Timm family genes, involved in the transport of proteins across the mitochondrial intermembrane space, were present in the downregulated clustered areas (Timm8b, Timm9, and Timm21). Six of the family members present in array data were downregulated, but only Timm 21 and $8 b$ with statistical significance (Fig. 8).
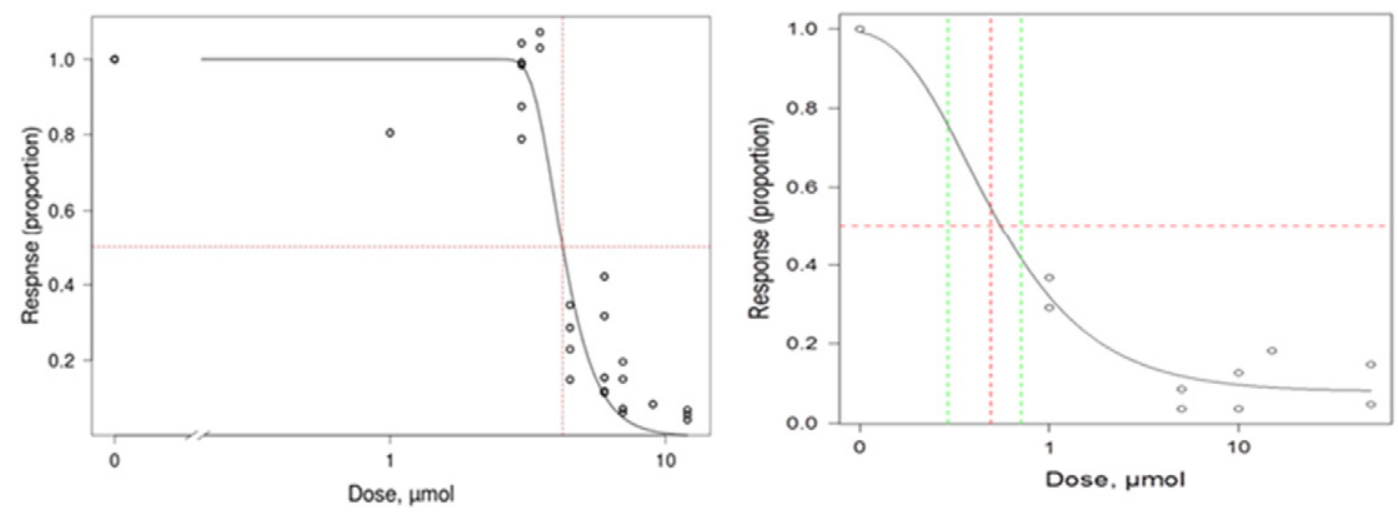

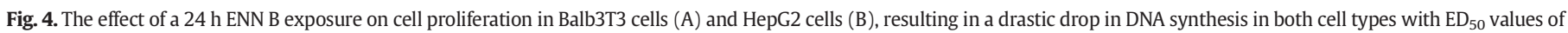
$4.2 \pm 0.06 \mu \mathrm{M}$ ENN B in Balb 3 T3 cells and $0.50 \pm 0.09 \mu \mathrm{M}$ ENN B in HepG2 cells. 
Changes in early apoptotic cell populations in Balb 3 T 3 cells post EnnB exposure

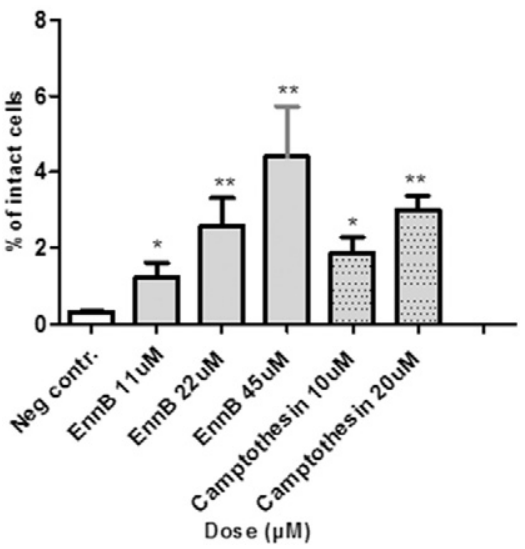

Fig. 5. Flow cytometer studies on Annexin V-FITC/PI labeled Balb 3T3 cells, after 24-h EnnB treatment. Positive control cells were treated with camptothesin and negative control cells with fresh growth media. An $11 \mu \mathrm{M}$ dose of EnnB $(\approx$ ED50) increased the proportion of early apoptotic cells from $0.3 \%$ (negative control cells) to $1.25 \%$. The proportion of early apoptotic cells increased in a dose-dependent manner to $2.5 \%$ in cells treated with $22 \mu \mathrm{M}$ EnnB and $4.4 \%$ with $45 \mu \mathrm{M}$ EnnB. The statistical significance of the difference between treated cells and negative control is denoted as: ${ }^{*}(p \leq 0.05),{ }^{* *}(p \leq 0.005)$.

RT-qPCR was used to confirm the expression results of the microarray data for a few selected genes, Ndufs4 and Timm21 (the genes with most significant fold change among the studied gene families mentioned above), resulting in downregulated relative expression due to EnnB exposure, thus supporting array data results (Fig. 9).

The microarray gene expression study did not reveal any drastic changes in the gene expression of the key proteins involved in cell proliferation compared to the negative control (Table 3). Cyclin-dependent kinases, formed from a catalytic kinase together with regulatory cyclins, play a major role in cell cycle control (Lewin, 2000). The expression of most of these kinases and cyclins remained unchanged compared to the unexposed control following exposure to EnnB for $4 \mathrm{~h}$. No significant enrichment in GO terms was discovered among up- or downregulated genes related to cell proliferation. This may be because primary cells proliferate poorly under in vitro conditions, unless chemically stimulated by growth factors such as platelet-derived growth factor (PDGF), and did not provide a means to efficiently study this endpoint in our experimental settings. However, in array data, the expression of three cyclins (B2, G1, and L2) was significantly changed compared to the negative control following 4-h EnnB $(10 \mu \mathrm{M})$ treatment. Cyclins B2 and G2 were

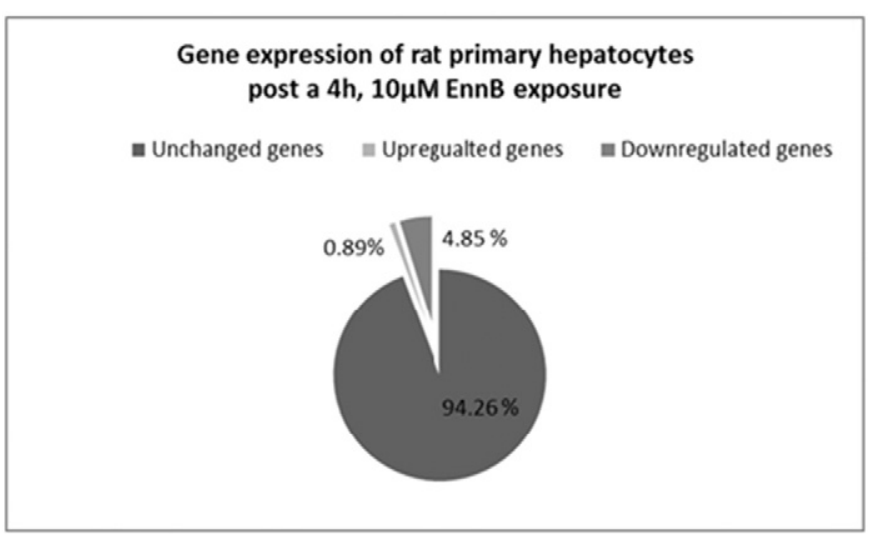

Fig. 6. A 4-h exposure of rat primary hepatocytes to $10 \mu \mathrm{M}$ EnnB caused a $4.85 \%$ downregulation and only a $0.89 \%$ upregulation of the genes of the rat total genome compared to the negative control. The smaller dose $(1 \mu \mathrm{M})$ changed (upregulated) the expression of only 2 genes: Sipa1/2 (signal-induced proliferation-associated 1-like protein 2) involved in signal transduction (GTPase mediated) and an unknown gene.
Table 1

The most and p-values enriched GO terms regarding biological function among downregulated and upregulated genes (Fisher's exact test). Enrichment among upregulated genes was not statistically significant, as FDR values were too high. FDR values $\leq 0.01$ and $\mathrm{p}$-values $\leq 0.05$ were considered significant.

\begin{tabular}{|c|c|c|c|}
\hline \multicolumn{2}{|c|}{$\begin{array}{l}\text { The most enriched GO terms among downregulated } \\
\text { genes }\end{array}$} & \multirow{2}{*}{$\begin{array}{l}\text { FDR value } \\
2.33 \mathrm{E}-09\end{array}$} & \multirow{2}{*}{$\begin{array}{l}\text { p-Value } \\
4.53 \mathrm{E}-12\end{array}$} \\
\hline GO:0008152 & Metabolic process & & \\
\hline GO:0019941 & $\begin{array}{l}\text { Modification-dependent protein catabolic } \\
\text { process }\end{array}$ & $1.01 \mathrm{E}-08$ & $2.02 \mathrm{E}-11$ \\
\hline G0:0043632 & $\begin{array}{l}\text { Modification-dependent macromolecule } \\
\text { catabolic process }\end{array}$ & $1.34 \mathrm{E}-08$ & $2.82 \mathrm{E}-11$ \\
\hline GO:0006511 & $\begin{array}{l}\text { Ubiquitin-dependent protein catabolic } \\
\text { process }\end{array}$ & $3.60 \mathrm{E}-08$ & $7.94 \mathrm{E}-11$ \\
\hline GO:0044237 & Cellular metabolic process & $5.08 \mathrm{E}-08$ & $1.15 \mathrm{E}-10$ \\
\hline GO:0070647 & $\begin{array}{l}\text { Protein modification by small protein } \\
\text { conjugation or removal }\end{array}$ & $5.70 \mathrm{E}-08$ & $1.34 \mathrm{E}-10$ \\
\hline GO:0044257 & Cellular protein catabolic process & $1.27 \mathrm{E}-07$ & $3.05 \mathrm{E}-10$ \\
\hline GO:0030163 & Protein catabolic process & $5.64 \mathrm{E}-07$ & $1.42 \mathrm{E}-09$ \\
\hline GO:0051603 & $\begin{array}{l}\text { Proteolysis involved in cellular protein } \\
\text { catabolic process }\end{array}$ & $6.50 \mathrm{E}-07$ & $1.70 \mathrm{E}-09$ \\
\hline GO:0044260 & $\begin{array}{l}\text { Cellular macromolecule metabolic } \\
\text { process }\end{array}$ & $1.69 \mathrm{E}-06$ & $4.63 \mathrm{E}-09$ \\
\hline GO:0032446 & $\begin{array}{l}\text { Protein modification by small protein } \\
\text { conjugation }\end{array}$ & $3.21 \mathrm{E}-06$ & $9.04 \mathrm{E}-09$ \\
\hline GO:0071704 & Organic substance metabolic process & $4.78 \mathrm{E}-06$ & $1.40 \mathrm{E}-08$ \\
\hline GO:0044238 & Primary metabolic process & $4.82 \mathrm{E}-06$ & $1.43 \mathrm{E}-08$ \\
\hline GO:0044267 & Cellular protein metabolic process & $1.29 \mathrm{E}-05$ & $4.50 \mathrm{E}-08$ \\
\hline GO:0016567 & Protein ubiquitination & $1.44 \mathrm{E}-05$ & $5.09 \mathrm{E}-08$ \\
\hline GO:0043412 & Macromolecule modification & $3.02 \mathrm{E}-05$ & $1.25 \mathrm{E}-07$ \\
\hline GO:0043170 & Macromolecule metabolic process & $5.49 \mathrm{E}-05$ & $2.36 \mathrm{E}-07$ \\
\hline GO:0006464 & Cellular protein modification process & $6.38 \mathrm{E}-05$ & $2.81 \mathrm{E}-07$ \\
\hline GO:0036211 & Protein modification process & $6.38 \mathrm{E}-05$ & $2.81 \mathrm{E}-07$ \\
\hline GO:0010498 & Proteasomal protein catabolic process & $1.06 \mathrm{E}-04$ & $4.89 \mathrm{E}-07$ \\
\hline GO:0006184 & Obsolete GTP catabolic process & $1.55 \mathrm{E}-04$ & $7.23 \mathrm{E}-07$ \\
\hline GO:0043161 & $\begin{array}{l}\text { Proteasome-mediated } \\
\text { ubiquitin-dependent protein catabolic } \\
\text { process }\end{array}$ & $2.68 \mathrm{E}-04$ & $1.30 \mathrm{E}-06$ \\
\hline GO:0031329 & Regulation of cellular catabolic process & $4.83 \mathrm{E}-04$ & $2.52 \mathrm{E}-06$ \\
\hline GO:0000209 & Protein polyubiquitination & $6.89 \mathrm{E}-04$ & $3.74 \mathrm{E}-06$ \\
\hline GO:0019538 & Protein metabolic process & $7.50 \mathrm{E}-04$ & $4.11 \mathrm{E}-06$ \\
\hline GO:0034660 & ncRNA metabolic process & $9.15 \mathrm{E}-04$ & $5.11 \mathrm{E}-06$ \\
\hline GO:0044265 & Cellular macromolecule catabolic process & $1.15 \mathrm{E}-03$ & $6.54 \mathrm{E}-06$ \\
\hline GO:0044248 & Cellular catabolic process & $2.38 \mathrm{E}-03$ & $1.43 \mathrm{E}-05$ \\
\hline GO:0009057 & Macromolecule catabolic process & $2.42 \mathrm{E}-03$ & $1.46 \mathrm{E}-05$ \\
\hline GO:0009894 & Regulation of catabolic process & $7.62 \mathrm{E}-03$ & $5.35 \mathrm{E}-05$ \\
\hline GO:2000641 & $\begin{array}{l}\text { Regulation of early endosome to late } \\
\text { endosome transport }\end{array}$ & $8.18 \mathrm{E}-03$ & $5.87 \mathrm{E}-05$ \\
\hline GO:0007005 & Mitochondrion organization & $8.43 \mathrm{E}-03$ & $6.09 \mathrm{E}-05$ \\
\hline \multicolumn{4}{|c|}{ The most enriched Go terms among Upregulated genes } \\
\hline GO:0,007205 & $\begin{array}{l}\text { Protein kinase C-activating G-protein } \\
\text { coupled receptor signaling pathway }\end{array}$ & $2.33 \mathrm{E}-01$ & $7.84 \mathrm{E}-05$ \\
\hline GO:1903300 & Negative regulation of hexokinase activity & $9.33 \mathrm{E}-01$ & $8.24 \mathrm{E}-04$ \\
\hline GO:0033132 & $\begin{array}{l}\text { Negative regulation of glucokinase } \\
\text { activity }\end{array}$ & $9.33 \mathrm{E}-01$ & $8.24 \mathrm{E}-04$ \\
\hline GO:0006325 & Chromatin organization & $9.33 \mathrm{E}-01$ & $9.58 \mathrm{E}-04$ \\
\hline
\end{tabular}

downregulated and cyclin L2 upregulated. Cyclin B2 is involved in growth factor beta-mediated cell control and cyclin G2 is involved in DNA damage-induced G2/M-phase arrest. The M-phase kinase inactivating protein Wee1 was also downregulated. The upregulated L2 cyclin is involved in RNA polymerase II regulation and pre-RNA splicing (Table 3).

Enrichment analysis did not reveal significant enrichment among GO terms linked to the third endpoint of our study, apoptosis. However, borderline enrichment among downregulated genes was observable (GO terms apoptotic mitochondrial changes, FDR $\leq 3.3 \mathrm{E}-01$, and regulation of apoptotic DNA fragmentation, FDR $\leq 6.4 \mathrm{E}-01$ ). Enrichment among upregulated genes was not detected even at this modest borderline significance level, indicating that upregulation of genes is not associated with apoptotic processes. Furthermore, the expression of central genes involved in apoptosis (e.g. caspase-3, -8, -9, Tradd, Bid, Apaf-1, Aifm) were downregulated or unchanged compared to the unexposed control in microarray studies (Table 4). Notably, both caspase-3 and Aifm, which are executing molecules in the death receptor pathway 
Table 2

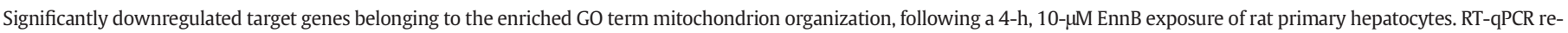
sults are reported as the change in expression compared to untreated cells, the expression of which is referred to as 1.

\begin{tabular}{|c|c|c|c|c|}
\hline \multicolumn{4}{|c|}{ Target genes of the enriched GO term: GO:0007005 } & \multirow{2}{*}{$\frac{\text { Mitochondrion organization }}{\text { Gene function (Reference: www.genecards.org) }}$} \\
\hline Gene & $\begin{array}{l}\text { Array data: } \\
\text { log2 fold change }\end{array}$ & $\begin{array}{l}\text { Array data: } \\
\text { q-value }\end{array}$ & RT-qPCR & \\
\hline NDUFS4 & -1.086106118 & $1.65 \mathrm{E}-07$ & 0.65 & NADH dehydrogenase (ubiquinone) Fe-S protein 4. A subunit of complex I. \\
\hline Timm21 & -1.880576292 & $2.97 \mathrm{E}-09$ & 0.65 & $\begin{array}{l}\text { Translocase of inner mitochondrial membrane } 21 \text { homolog. Involved in the translocation of proteins } \\
\text { across the mitochondrial inner membrane. Required for assembly of complex I and complex IV. }\end{array}$ \\
\hline Timm8b & -1.114771134 & $2.57 \mathrm{E}-07$ & & $\begin{array}{l}\text { Translocase of inner mitochondrial membrane } 8 \text { homolog B. Guide proteins across the mitochondrial } \\
\text { intermembrane space before they are added into the mitochondrial inner membrane. }\end{array}$ \\
\hline Tomm5 & -1.849071608 & $2.90 \mathrm{E}-07$ & & TOMM5 (translocase of outer mitochondrial membrane 5 homolog (yeast)) \\
\hline Mpv171 & -1.038709587 & $7.78 \mathrm{E}-05$ & & Mitochondrial membrane protein17-like protein. Regulates the genes of antioxidant enzymes. \\
\hline Malsu1 & -1.016988016 & $9.61 \mathrm{E}-06$ & & $\begin{array}{l}\text { Mitochondrial assembly ribosomal large subunit protein. Preventing the formation of functional } \\
\text { ribosomes, thus repressing translation. }\end{array}$ \\
\hline Nrf1 & -1.228319951 & $1.91 \mathrm{E}-05$ & & $\begin{array}{l}\text { Nuclear respiratory factor } 1 \text { a. Transcription factor activating some key genes regulating cellular growth } \\
\text { and respiration, heme biosynthesis and mitochondrial DNA transcription and replication (ref } \\
\text { Wikipedia) }\end{array}$ \\
\hline $\mathrm{Tfb} 2 \mathrm{~m}$ & -1.003915687 & $8.77 \mathrm{E}-05$ & & $\begin{array}{l}\text { Transcription factor B2, mitochondrial. Dimethylates mitochondrial 12S RNA and is required for } \\
\text { transcription of mitochondrial DNA. }\end{array}$ \\
\hline Trmt10c & -2.047727163 & $2.91 \mathrm{E}-08$ & & $\begin{array}{l}\text { Mitochondrial ribonuclease P protein } 1 \text {. A subunit of the mitochondrial ribonuclease P, involved in } 5^{\prime} \\
\text { processing of mitochondrial tRNAs. }\end{array}$ \\
\hline Dctn6 & -1.010134783 & $1.60 \mathrm{E}-07$ & & Dynactin subunit 6. Dynactins are involved with intracellular.and mitochondria biogenesis. \\
\hline Dnm1 & -1.149074708 & $5.85 \mathrm{E}-08$ & & $\begin{array}{l}\text { Dynamin } 1 \text { is involved in clathrin-mediated endocytosis } \\
\text { and vesicular trafficking processes. }\end{array}$ \\
\hline Smcr7l & -1.218873937 & $4.48 \mathrm{E}-07$ & & Mitochondrial dynamic protein MID51. Regulates mitochondrial fission. \\
\hline Atg3 & -1.400830673 & $2.64 \mathrm{E}-07$ & & $\begin{array}{l}\text { Autophagy related protein } 3 \text {. Enzyme required for the cytoplasm to vacuole transport (Cvt), autophagy } \\
\text { and mitochondrial homeostasis. }\end{array}$ \\
\hline Tubb5 & -1.264937216 & $3.13 \mathrm{E}-07$ & & $\begin{array}{l}\text { Tubulin, beta polypeptide. Microtubules act as a scaffold to determine } \\
\text { cell shape, and provide a backbone for cell organelles and vesicles to move on. }\end{array}$ \\
\hline Golph3 & -1.07172804 & $9.47 \mathrm{E}-07$ & & Golgi phosphoprotein 3. Links golgi membranes to the cytoskeleton \\
\hline magmas & -1.242760796 & $5.04 \mathrm{E}-07$ & & $\begin{array}{l}\text { Mitochondria-associated granulocyte macrophage CSF signaling molecule [Source: RefSeq } \\
\text { peptide;Acc:NP_001093606] }\end{array}$ \\
\hline Sh3glb1 & -1.062385706 & $1.90 \mathrm{E}-07$ & & $\begin{array}{l}\text { SH3-domain GRB2-like endophilin B1. The encoded protein interacts with the proapoptotic member of } \\
\text { the Bcl-2 family Bcl-2-associated X protein (Bax) and may be involved in regulating apoptotic signaling } \\
\text { and in. } \\
\text { maintaining mitochondrial morphology }\end{array}$ \\
\hline $\mathrm{Bcl} 2 \mathrm{l} 11$ & -1.015601743 & 0.0004518 & & Bcl-2-like protein 11. Induces apoptosis and anoikis. \\
\hline Tnfsf10 & -1.041252965 & $8.84 \mathrm{E}-05$ & & $\begin{array}{l}\text { Tumor necrosis factor (ligand) superfamily, member } 10 \text {. A cytokine. Associated with the activation of } \\
\text { MAPK8/JNK, caspase } 8 \text {, and caspase } 3 \text {. }\end{array}$ \\
\hline Aifm1 & -1.03404913 & $1.51 \mathrm{E}-07$ & & $\begin{array}{l}\text { Apoptosis-inducing factor 1, mitochondrial [Source: UniProtKB/Swiss-Prot;Acc:Q9JM53] Functions as } \\
\text { an antiapoptotic factor in normal mitochondria and as a proapoptotic factor in a caspase-independent } \\
\text { pathway. }\end{array}$ \\
\hline Casp3 & -1.604286218 & $8.19 \mathrm{E}-07$ & & Caspase- 3 executioner caspase. \\
\hline Atg12 & -1.61538308 & $5.19 \mathrm{E}-08$ & & ATG12 is involved in autophagy. Interaction with anti-apoptotic members of the Bcl-2 family \\
\hline Cisd2 & -1.217212828 & $3.6 \mathrm{E}-07$ & & $\begin{array}{l}\text { CDGSH iron sulfur domain-containing protein } 2 \text {. A zinc finger protein that is required for } \\
\text { BCL2-mediated depression of endoplasmic reticulum } \mathrm{Ca}(2+) \text { stores during autophagy. }\end{array}$ \\
\hline ppp2cb & -1.48270962 & $3.06 \mathrm{E}-07$ & & $\begin{array}{l}\text { Phosphatase } 2 \text { A catalytic subunit. Protein phosphatase } 2 \mathrm{~A} \text { is one of the four major Ser/Thr } \\
\text { phosphatases, involved in the negative control of cell growth and division. }\end{array}$ \\
\hline Tmem11 & -1.549475024 & $3.03 \mathrm{E}-06$ & & Transmembrane protein 11 , mitochondrial. \\
\hline Ywhag & -1.367469554 & $1.61 \mathrm{E}-06$ & & 14-3-3 protein gamma, N-terminally processed [Source: UniProtKB/Swiss-Prot;Acc:P61983] \\
\hline Gabarapl1 & -1.300833291 & $4.37 \mathrm{E}-08$ & & $\begin{array}{l}\text { Gamma-aminobutyric acid receptor-associated protein-like } 1 \text { [Source: } \\
\text { UniProtKB/Swiss-Prot;Acc:Q0VGK0] }\end{array}$ \\
\hline Mef2a & -1.129488547 & $3.04 \mathrm{E}-07$ & & $\begin{array}{l}\text { Myocyte enhancer factor 2. A transcription factor that activates many muscle-specific, growth } \\
\text { factor-induced, stress induced genes. Control of cell growth, survival and apoptosis via p38 MAPK } \\
\text { signaling. }\end{array}$ \\
\hline Map3k1 & -1.091264569 & 0.0006314 & & $\begin{array}{l}\text { Mitogen-activated protein kinase kinase kinase 1. Involved in the kinase signal transduction cascade. } \\
\text { Activates the ERK and JNK kinase pathways }\end{array}$ \\
\hline Rrm2b & -1.64098889 & $2.17 \mathrm{E}-08$ & & $\begin{array}{l}\text { Ribonucleotide reductase M2 B. Has an important role in cell survival by repairing damaged DNA. } \\
\text { Supplies deoxyribonucleotides for DNA repair in cells arrested at G1 or G2 }\end{array}$ \\
\hline Mterfd2 & -1.120340882 & $1.39 \mathrm{E}-07$ & & mTERF domain-containing protein 2 [Source: UniProtKB/Swiss-Prot;Acc:Q4G078] \\
\hline Bnip3l & -1.684610402 & $1.21 \mathrm{E}-07$ & & $\begin{array}{l}\text { BCL2/adenovirus E1B } 19 \text { kDa protein-interacting protein 3-like [Source:RefSeq } \\
\text { peptide;Acc:NP_543164] }\end{array}$ \\
\hline $\mathrm{Cln} 8$ & -1.46642584 & $1.13 \mathrm{E}-07$ & & $\begin{array}{l}\text { Ceroid-lipofuscinosis, neuronal } 8 \text {. Involved in cell proliferation at neuronal differentiation and in } \\
\text { protection against cell death. }\end{array}$ \\
\hline Cxadr & -1.107408415 & $1.33 \mathrm{E}-05$ & & Coxsackievirus and adenovirus receptor homolog [Source: UniProtKB/Swiss-Prot;Acc:Q9R066] \\
\hline Mpv17l & -1.038709587 & $7.78 \mathrm{E}-05$ & & $\begin{array}{l}\text { Mpv17 transgene, kidney disease mutant-like (Uncharacterized protein [Source: } \\
\text { UniProtKB/TrEMBL;Acc:D4A908] }\end{array}$ \\
\hline
\end{tabular}

and mitochondrial pathway, respectively, were significantly downregulated in array data (fold change $\leq-1$ ). Furthermore, in RT-qPCR studies, the change in expression compared to the unexposed control was not significant among any caspase gene tested (Fig. 10).

In array data, genes involved in apoptosis inhibition, c-Jun (fold change 0.8), Birc3 (fold change 0.7), and Faim3 (fold change 0.8), were somewhat upregulated, suggesting the inhibition of apoptotic cascades.
Together, these results indicate that apoptotic cell death is not involved in the cytotoxicity of EnnB in rat primary hepatocytes.

\section{Discussion}

Although enniatins (Enns) have not been reported to be involved in any human outbreaks, harmful effects on humans and livestock cannot 

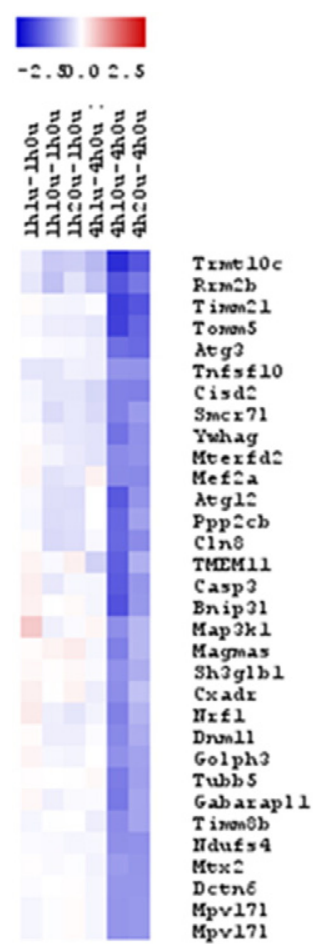
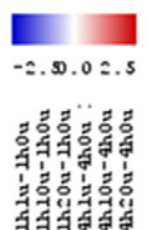
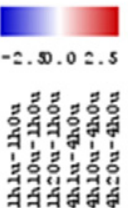

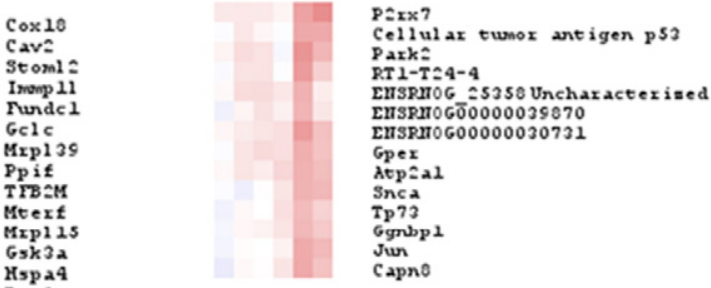

Cellular twox antigen p53

Capno

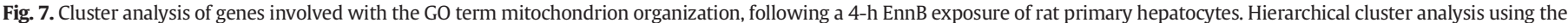

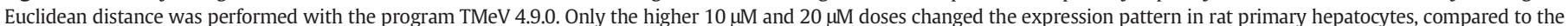

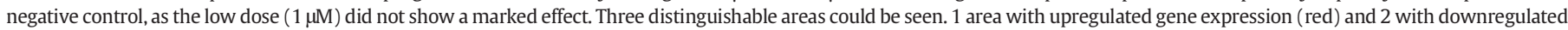
expression (blue). Several of genes belonging to the Ndufs gene family (Ndfus4, 1, 8) and Timm gene family (Timm8b, 21, 9) are represented in downregulated cluster areas.

be ruled out, especially on a long-term and low-dose basis, as only a very limited amount of subacute or chronic in vivo data is available. Additionally, numerous in vitro studies point towards cytotoxic effects of Enns on several different cell types at relatively low concentrations (Gammelsrud et al., 2012, Ivanova et al., 2012, Dornetshuber et al., 2009b). The cytotoxic effects of Enns have long been associated with the ionophoric properties of biological membranes, as they are thought to form sandwich-structured dimers transporting cations (especially $\mathrm{k}+$ ) across biological membranes (Ovchinnikov et al., Kamyar et al., 2004), but the exact mechanism of toxicity is still unclear.

Expression of Ndufs and Timm F amily of Genes

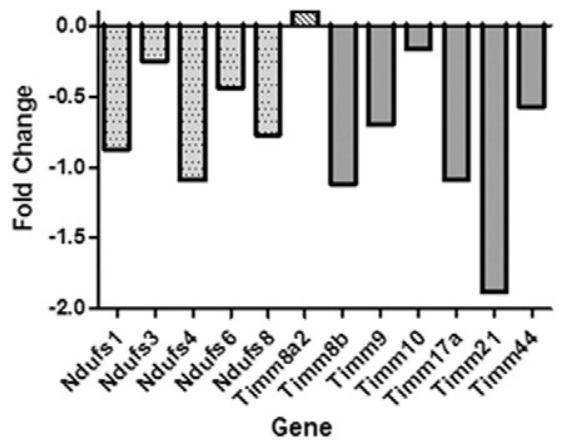

Fig. 8. Gene expression data of microarray analysis post a 4-h, 10- $\mathrm{MM}$ EnnB exposure of the Ndufs-family of genes (subunits of complex I), required in the electron flow chain in mitochondria leading to ATP production. Although only Ndufs4 is significantly downregulated (fold change $\geq 1$ ), the overall expression trend among the Ndufs family of genes is repressed. Ndufs are NADH dehydrogenase Fe-S proteins and parts of the iron-sulfur fragment of complex I. Ndufs 1 is the largest subunit of the enzyme. (Ref: www.Genecards.org) The Timm family of genes is involved in the transport of proteins in the mitochondrial intermembrane space and incorporation of proteins in the inner mitochondrial membrane.
The aim of this investigation was to determine the cytotoxic effects of enniatin B on the very sensitive mouse embryo fibroblast cell line Balb 3T3 and the hepatocyte HEPG2 cell line in relation to cellular energy metabolism, cell proliferation, and apoptotic cell death. Additionally, the mechanism of toxicity was examined on the basis of gene expression using rat primary hepatocytes and Affymetrix gene chip analysis. Primary hepatocytes were chosen for this study because they are considered to better correspond to in vivo studies than immortalized cell lines.

According to our results, Enn B was already cytotoxic to both cell lines (Balb 3T3 and HepG2) and rat primary hepatocytes at low $(\mu \mathrm{M})$ concentrations. In both cell lines, the levels of ATP and degree of cell proliferation were reduced in a very steeply declining manner, post a

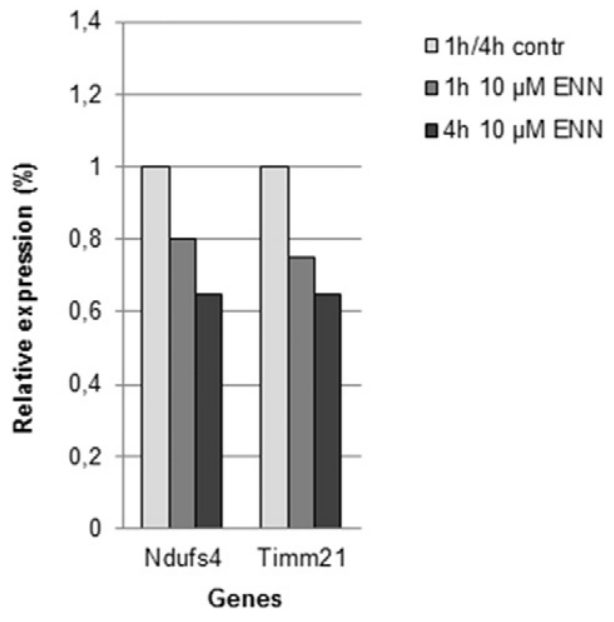

Fig. 9. Real-time quantitative RT-PCR analysis of mitochondrial genes Ndufs4 and Timm 21 in rat primary hepatocytes in response to $1 \mathrm{~h}$ and $4 \mathrm{~h}$ exposure to $10 \mu \mathrm{M}$ EnnB. Relative transcript abundance of non-treated cells ( $1 \mathrm{~h} / 4 \mathrm{~h}$ contr) at corresponding time points. 
Table 3

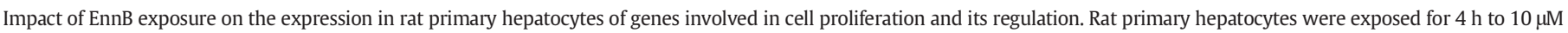
EnnB and analyzed using the Affymetrix rat whole genome gene chip.

\begin{tabular}{|c|c|c|}
\hline Gene & $\begin{array}{l}\text { Fold change } \\
\text { array data }\end{array}$ & Function (Reference: www.genecards.org) \\
\hline Cyclin A1 & 0.56 & A cyclins bind both CDK2 and CDC2 kinases, the other active in G1/S phase, the other in G2/M-phase. \\
\hline Cyclin A2 & -0.19 & \\
\hline Cyclin B1 & - & Associate with Cdc2 kinase, the "M-phase kinase", \\
\hline Cyclin $\overline{\mathrm{B}} 2$ & -1.53 & \\
\hline Cyclin C & -0.87 & Involved in phosphorylation of RNA polymerase II \\
\hline Cyclin D1 & -0.2 & D cyclins form a complex with and functions as a regulatory subunit of CDK4 or CDK6, required for cell cycle G1/S transition \\
\hline Cyclin D2 & 0.5 & \\
\hline Cyclin D3 & -0.37 & \\
\hline Cyclin E1 & 0.51 & E cyclins are regulatory subunits of CDK2 and their activity is required for cell cycle G1/S transition. \\
\hline Cyclin E2 & -0.6 & \\
\hline Cyclin F & -0.8 & Cyclin F belong to the F-box protein family, subunits of the ubiquitin protein ligase complex \\
\hline Cyclin G1 & -2.23 & Involved in $\mathrm{p} 53$ mediated $\mathrm{G} 2 / \mathrm{M}$ phase arrest if DNA is damaged. \\
\hline Cyclin G2 & -0.58 & \\
\hline Cyclin $\mathrm{H}$ & -0.4 & Regulates CDK7, the catalytic subunit of the CDK-activating kinase (CAK). \\
\hline Cyclin I & -0.9 & The function has not been determined. \\
\hline Cyclin K & -0.76 & May have a role in regulating CDK and RNA polymerase II activities. \\
\hline Cyclin L1 & 0.83 & Pre RNA-splicing, RNA polymerase II regulation \\
\hline Cyclin L2 & 1.7 & \\
\hline Cyclin T2 & -0.21 & Cyclin T2 and CDK9 were found to be subunits transcription elongation factor $p$-TEFb. \\
\hline Cyclin Y & -0.33 & Regulatory subunit of CDk14 and 16. \\
\hline \multicolumn{3}{|r|}{ 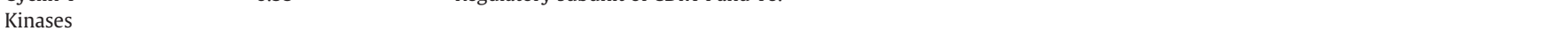 } \\
\hline Cdc2 or Cdk1 & -0.1 & Cyclin dependent kinase 2 \\
\hline Cdk2 & -0.57 & Cyclin dependent kinase 4 \\
\hline Cdk4 & -0.04 & Cyclin dependent kinase5 \\
\hline Cdk5 & 0.16 & Cyclin dependent kinase 5 activator 1 \\
\hline Cdk5r1 & 0.48 & Cyclin dependent kinase 5 activator2 \\
\hline Cdk5r2 & 0.72 & Cyclin dependent kinase 6 \\
\hline Cdk6 & -0.1 & \\
\hline \multicolumn{3}{|l|}{ Regulators } \\
\hline $\mathrm{Rb} 1$ or $\mathrm{pRB}$ & -0.6 & A negative regulator of the cell cycle. Acts as a transcription repressor of E2F1 target genes. \\
\hline E2F1 & 0.64 & A member of the E2F family of transcription factors and mediates both cell proliferation and apoptosis \\
\hline E2F4 & -0.5 & Transcription activator that controls cell-cycle progression fromG1 to $S$ phase \\
\hline E2F5 & -0.9 & Transcriptional activator (early responses of resting cells to growth factor stimulation) \\
\hline E2F6 & -1.4 & Inhibitor of E2F-dependent transcription \\
\hline Wee1 & -1.33 & Catalyzes the inhibitory tyrosine phosphorylation of $\mathrm{CDC} 2 /$ cyclin B kinase \\
\hline Trp53 & & A tumor suppressor protein. Induces growth arrest or apoptosis depending on the physiological circumstances and cell type. \\
\hline
\end{tabular}

24-h exposure to EnnB, indicating a severe cytotoxic effect (Figs 3 and 4), with $\mathrm{ED}_{50}$ values below $8.4 \mu \mathrm{M}$. Nevertheless, the cell lines remained alive and showed a rather normal morphology as seen in Fig. 1A and B. Furthermore, the majority of the Balb 3T3 cells remained intact in the cell viability assay, as no leakage of AK through the cell membrane was measured (Fig 2). The cell density, however, was much lower than in culture plates of negative control cells supporting the finding of a decrease in DNA synthesis and cell division.

Interestingly, the effect of EnnB on rat primary hepatocyte morphology was very different from that of the two cell lines. An exposure time of only $4-5 \mathrm{~h}$ to $10 \mu \mathrm{M}$ EnnB caused the majority of the cells to round up and detach from the plate surface and die in a necrotic manner (Fig $1 \mathrm{C}$ and $\mathrm{D}$ ). One reason could be stress due to cryopreservation and the new artificial environment and medium. The cells were, however, acclimatized for a long period $(\mathrm{o} / \mathrm{n})$ before exposure, and an optimized medium was used in all steps. Moreover, the morphology of negative control cells remained normal.

As our data indicate reduced ATP levels post EnnB exposure in the cell lines, down regulation of the genes involved with energy metabolism were expected in the primary hepatocytes. Enrichment analysis of microarray data on exposed primary hepatocytes revealed that genes involved in metabolic and catabolic processes were generally downregulated, which could point towards cellular energy deprivation, as for Balb 3T3 and HEPG2 cell lines. The enrichment results could, furthermore, refer to mitochondrial dysfunction given that GO terms linked with "mitochondrion organization" were significantly enriched among the downregulated genes. No enrichment among upregulated genes was discovered. Further cluster analysis of the gene expression patterns of the enriched genes, associated with mitochondrion organization, revealed the presence of three gene clusters, two consisting of downregulated genes and one of upregulated genes (Fig. 7). Three genes of the Ndufs gene family, Ndufs1, 4, and 8, were found within these downregulated gene clusters (Fig. 7), indicating that EnnB exposure may alter the function of the mitochondrial electron transport chain (ETC) and hence, ATP production. Ndufs gene family members are involved in cellular respiration, as they are subunits of the mitochondrial ETC protein complex I (Breuer et al., 2013). This complex consists of 45 subunits, and the gene products of the Ndufs genes are NADH dehydrogenase iron-sulfur protein subunits (Breuer et al., 2013, GeneCards, 2015). The iron-sulfur protein cluster of complex I transfers the electrons to ubiquinone, the next carrier of the ETC (Garrett and Grisham, 1999). Ndufs1 is the largest subunit of complex I and the Ndufs 4 gene encodes an $18 \mathrm{kDa}$ subunit, phosphorylated by intracellular cAMP, leading to the stimulation of complex I (Petruzzella et al., 2001). Another clustered family of downregulated genes includes the Timm gene family. The gene product of the Timm 21 gene is a translocase of the mitochondrial inner membrane and is required for the assembly of complex I and complex IV (GeneCards, 2015), and the gene Timm $8 b$, the product of which guides membrane proteins through the intermembrane space as they are imbedded in the inner membrane of the mitochondria (The NCBI, 2015).

Downregulation of these genes, affecting complex I function and assembly, could provide an explanation for the low cellular ATP levels after exposure to EnnB, with a different outcome depending on the cell type: a loss of cell proliferation in Balb 3T3 and HepG2 cell lines and necrotic cell death in primary hepatocytes. Mitochondrial dysfunction has been reported to be induced by a number of chemicals (drugs). Drugs can directly affect the DNA transcription of ETC complexes or 
Table 4

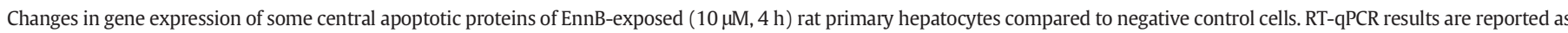
the change in expression compared to untreated cells, the expression of which is referred to as 1 .

\begin{tabular}{|c|c|c|c|}
\hline \multicolumn{4}{|c|}{ Changes in gene expression of central apoptotic proteins } \\
\hline Gene name & Array data: $\log 2$ fold change & RT-qPCR & Gene function (Reference: www.genecards.org) \\
\hline Caspase 1 & +0.5 & 0.61 & Activates inflammatory cytokines interleukine- $1 \beta$ and -18 and induce necrosis \\
\hline Caspase 2 & 0.001 & & $\begin{array}{l}\text { Involved in the activation of caspases responsible for apoptosis. May be involved in } \\
\text { Alzheimer's disease. }\end{array}$ \\
\hline Caspase 3 & -1.6 & 0.94 & Executioner caspase, responsible for apoptosis execution. \\
\hline Caspase4 & -0.8 & & Involved in ER stress-induced apoptosis. Cleaves caspase-1 \\
\hline Caspase7 & -0.6 & 0.96 & Executioner caspase, responsible for apoptosis execution. \\
\hline Caspase8 & -0.14 & & Initiator caspase, the first caspase to be activated in the death receptor pathway. \\
\hline Caspase9 & -0.15 & 1.20 & Initiator caspase, activates caspase- 3 \\
\hline Caspase12 & -1.4 & & Initiator caspase, mediates apoptosis in response to ER stress in rodents. \\
\hline Caspase14 & +0.5 & & May be involved in keratinocyte differentiation, and skin barrier formation. \\
\hline Casp8ap2 & -0.85 & & Caspase- 8 associated protein 2 \\
\hline TRADD & -0.67 & & TNF (TNFRSF1A)-associated death domain \\
\hline Bid & -0.3 & & $\begin{array}{l}\text { BH3-interacting domain death agonist. Required for the release of cytochrome C from } \\
\text { mitochondria. (Ref Genes VII) }\end{array}$ \\
\hline Apaf-1 & -0.5 & & Apoptotic peptidase activating factor 1 \\
\hline Faslg & 0.01 & & $\begin{array}{l}\text { Interaction of FAS with this ligand is critical in triggering apoptosis of some types of } \\
\text { cells }\end{array}$ \\
\hline Daxx & -0.36 & & Death domain-associated protein 6. Mediates activation of the JNK pathway. \\
\hline Tp53 & -0.6 & & $\begin{array}{l}\text { TP53-dependent transcriptional repression leads to apoptosis. Act as a tumor } \\
\text { suppressor. }\end{array}$ \\
\hline Aifm & -1.03 & 0.71 & $\begin{array}{l}\text { Apoptosis-inducing factor 1, mitochondrial. Aifs are involved in caspase independent } \\
\text { apoptosis and affects chromosome condensation and fragmentation. }\end{array}$ \\
\hline \multicolumn{4}{|r|}{ С } \\
\hline $\mathrm{Bcl} 2$ & +0.2 & & Prevents the release of cytochrome $\mathrm{C}$ from mitochondria, inhibiting apoptosis. \\
\hline Birc3 & +0.73 & & $\begin{array}{l}\text { Inhibits apoptosis by binding to tumor necrosis } \\
\text { factor receptor-associated factors TRAF1 and TRAF2 }\end{array}$ \\
\hline Birc6 & +0.68 & & $\begin{array}{l}\text { This protein inhibits apoptosis by facilitating the degradation of apoptotic proteins by } \\
\text { ubiquitination. }\end{array}$ \\
\hline Faim3 & +0.8 & & Fas apoptotic inhibitory molecule 3 \\
\hline
\end{tabular}

inhibit enzymes of the ETC and glycolysis, or reduce antioxidant levels via free radical production (Neustadt and Pieczenik, 2008). Barbiturates and the pesticide rotenone inhibit oxidative phosphorylation (ATP production) via effects on complex I, with a rapid fall in ATP levels in cells (Neustadt and Pieczenik, 2008). Based on our gene expression results, the rapid necrotic death of the rat primary hepatocytes and the drastic drop in ATP production in the cell lines (Balb 3T3, HepG2) might be due to starvation caused by the effects of enniatin B on complex I function and assembly, leading to dysfunction of the mitochondrial electron transfer chain. This is in line with studies by Tonshin et al., who reported similar findings, as Enns caused mitochondrial alteration and dysfunction in isolated rat liver mitochondria and human neural (Paju) cells, murine insulinoma (Min-6) cells, as well as in boar sperm cells. Enniatins caused a drop in the inner membrane potential and swelling

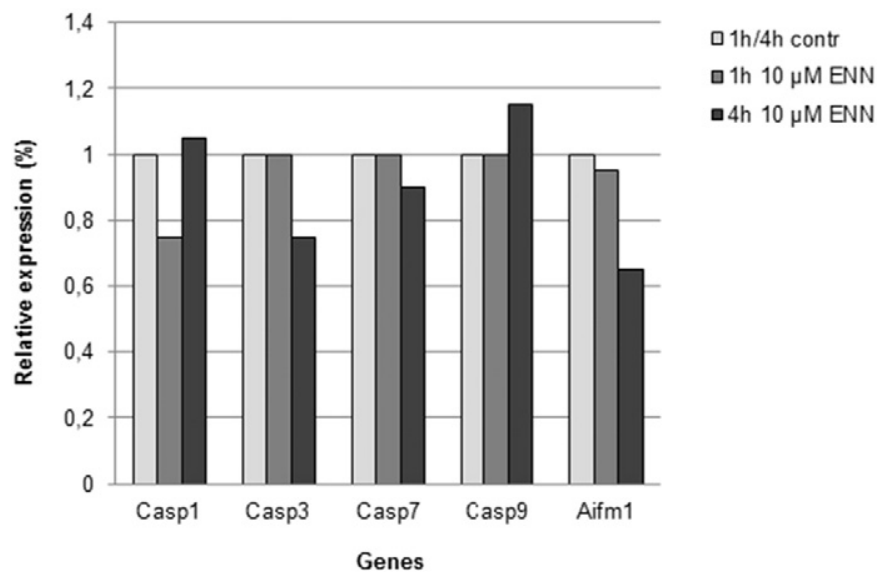

Fig. 10. Real-time quantitative RT-PCR analysis of the genes Aifm, caspase- $3,-7$, and -9 , involved in apoptosis, and caspase- 1 (inducing necrosis and inflammatory cytokines IL18 and $1 \beta$ ), in rat primary hepatocytes in response to $10 \mu \mathrm{M}$ EnnB exposure. Relative transcript abundance of non-treated cells ( $1 \mathrm{~h} / 4 \mathrm{~h}$ contr) at corresponding time points. of the isolated rat mitochondria in the presence of potassium $(\mathrm{K}+)$ (Tonshin et al., 2010). The mitochondrial membrane potential of intact cells (Paju, Min-6) was also altered and caused necrotic cell death. In sperm cells, enniatins caused a partial depolarization of the mitochondria as a result of $\mathrm{K}+$ influx into the mitochondrial matrix (causing swelling), and hyperpolarization of the sperm plasma membrane due to the efflux of potassium ions from the cell cytoplasm to the medium (Tonshin et al., 2010).

Moreover, by reducing ATP production, EnnB exposure resulted in decline in DNA synthesis (proliferation) in Balb 3T3 and HepG2 cell lines, measured by BrdU incorporation into DNA during the S-phase. Low levels of EnnB already had a drastic impact on cell proliferation $\left(\mathrm{ED}_{50}=4 \mu \mathrm{M}\right.$ and $0.5 \mu \mathrm{M}$, respectively, Fig. 4). The effect is even direr than for ATP production, but still lies in the same concentration range. The differences might be due to the different sensitivity of the two test methods.

Table 5

Primer sequences used in RT-qPCR analysis.

\begin{tabular}{ll}
\hline Gene name & Sequence $\left(\right.$ 5'-3') $\left.^{\prime}\right)$ \\
\hline FR3_Casp1 & GGAGGACATTTTCAGAAAGG \\
RR3_Casp1 & CTTGGATTCTTTAATGTCCTGG \\
FR3_Casp3 & GTGTGATTCTAAGTCATGGAG \\
RR3_Casp3 & CATATCATCGTCAGTTCCAC \\
FR3_Casp7 & CGTCTATAATGACTGCTCTTG \\
RR3_Casp7 & TGAGCTGTCAGATCCTTTATC \\
FR3_Casp9 & TTGTGAACATCTTCAATGGG \\
RR3_Casp9 & TGTCTTGAGAGGAAGTGAAG \\
FR3_Ndufs4 & CTTCAGTGCCAAAGAAGATG \\
RR3_Ndufs4 & CAGTCAAGCAGAAATGTAGC \\
FR_Timm21 & GAGACAACATGTCAGCTTTAC \\
RR_Timm21 & CAATAGATCTTTTAGGAGCCAC \\
FR3_Aifm1 & GGGAAGTAAGTCAATTACAG \\
RR3_Aifm1 & GAAGGATCTTCCCCATATTTC \\
FR3_SDHA & CCAGGACTTAGAATTTGTTCAG \\
RR3_SDHA & CATATCTCTCCATGAACCTTTC
\end{tabular}


The mitotic cell cycle is a complex and highly regulated process ending up in mitotic division of a cell. Cyclin-dependent kinases, together with regulators, play a major role in cell cycle control (Lewin, 2000). Our results of decreased cell proliferation are in line with previous studies (Gammelsrud et al., 2012), in which enniatin exposure caused cell cycle arrest in the G0/G1 phase and low cyclin D levels in murine macrophages and human carcinoma cells (HeLa), as well as, arrest in the G2 phase in Caco-2 cells (Ivanova et al., 2012). Low cyclin D levels might be the signal for cells to enter the G0 phase if growth conditions are altered (Lewin, 2000). Hence, ATP depression due to effects of EnnB on ETC complex I, might provide an explanation for our results of decreased cell proliferation (DNA synthesis) in the cell lines Balb 3T3 and HepG2.

The gene expression study on primary hepatocytes, did however, not reveal any drastic changes in the gene expression of the key proteins involved in cell proliferation compared to the negative control (Table 3 ), except for cyclin B, which was downregulated. Cyclin B is only active during mitosis. There was also no significant enrichment (GO terms) among up- or downregulated genes regarding cell proliferation. This indicates that the toxicity of high doses of EnnB (greater than $10 \mu \mathrm{M}$ ) is not due to cell cycle arrest in rat primary hepatocytes, but rather an event of necrotic cell death, manifested by swelling of the cells and detaching from the cell culture plate, possibly due to energy deprivation caused by mitochondrial dysfunction (effects on complex I).

The last of the studied endpoints was programmed cell death. Apoptosis can be induced by numerous factors. Unlike necrosis, apoptosis does not cause inflammation in tissues; instead, apoptotic cells undergo typical morphological changes. Apoptotic cells might, however, switch to necrosis if caspase or ATP levels become too low. In some occasions, low levels of chemicals/toxins induce apoptosis but higher doses might cause the cells to die via necrotic cell death (Elmore, 2007, Lewin, 2000).

In our study, exposure of mouse fibroblast Balb 3T3 cells to EnnB for $24 \mathrm{~h}$ and $48 \mathrm{~h}$ caused a slight increase in the early apoptotic cell population, studied by flow cytometric measurements using Annexin VFITC/PI staining. The effect was comparable to the positive control, camptothesin. The increase in the pro-apoptotic cell population after $24 \mathrm{~h}$ ranged from $0.3 \%$ (negative control cells) to $4.4 \%$ ( $45 \mu \mathrm{M}$ EnnB exposure). Exposure for $48 \mathrm{~h}$ had similar effects. Furthermore, the proportion of late apoptotic or necrotic cells appeared to increase with the EnnB dose; however, the change was not statistically significant. EnnB induction of apoptosis has also been reported in studies by Wätjen et al. and Dornetshuber et al. (Dornetshuber-Fleiss et al., 2014, Wätjen et al., 2009). In these surveys, enniatins caused caspase 3/7 activation in hepatoma H4IIE cells and caspase-7 activation in the KB-3-1 cell line, respectively, as well as nuclear fragmentation. Although EnnB slightly induced apoptosis in the Balb 3T3 cell line in our study, the outcome in rat primary hepatocytes was very different. In contradiction to the results of the cell lines, the gene expression results of rat primary hepatocytes did not support apoptotic cell death. The GO terms linked to apoptosis (apoptotic mitochondrial changes and regulation of apoptotic DNA fragmentation) were slightly, but not significantly, enriched among downregulated genes, while no enrichment was detected among the upregulated genes. Furthermore, the expression of central genes involved in apoptosis (e.g. caspase-3, -8, -9, TRADD, Bid, Apaf-1, Aifm) were only slightly downregulated or unchanged compared to the negative control in the microarray experiment. Notably, both caspase- 3 and Aifm, which are executing molecules in both the death receptor pathway and mitochondrial pathway, were significantly downregulated based on microarray and RT-qPCR studies (Table 4, Fig. 10). Furthermore, the $c$-JUN gene, involved in apoptosis inhibition via the TNF/NF-KB/IAP pathway, was marginally upregulated ( $\log _{2}$ fold change 0.8). $c$-JUN interacts with NF-KB, which results in the transcription of IAPs (inhibitors of apoptosis proteins, e.g. Birc3) $\left(\log _{2}\right.$ fold change 0.73 ), which can bind and inhibit caspases (Dubrez-Daloz et al., 2008, Liu and Lin, 2005). Together with the morphological findings (swelling of cells, rupture of plasma membrane), the gene expression results indicate that primary hepatocytes died via necrosis. The significance of apoptotic cell death in the overall toxic response of cells to EnnB could be considered minor, as the increase in the early apoptotic cell population in the studied cell lines was less than $5 \%$ compared to the negative control and cell death in primary hepatocytes was necrotic rather than apoptotic.

We report clear toxic outcomes of EnnB in in vitro assays and the data facilitates the understanding of the mode of action of EnnB at cellular level. However, if the toxic exposure levels are mirrored to the reported EnnB levels in foodstuffs, the levels in our experiments are by far higher (over 1000 times) than is possible in food intake.

\section{Conclusions}

EnnB exposure of cell lines Balb 3T3 and HepG2 altered cellular energy metabolism by reducing ATP levels, which already occurred at low exposure concentrations (below $10 \mu \mathrm{M}$ ). Concurrently, cell proliferation ceased and the proportion of early apoptotic cells slightly increased. Most of the cells, however, survived and cell morphology remained normal. The toxic response to EnnB in rat primary hepatocytes was quite different. The rat hepatocyte morphology was altered, as the cells swelled, the plasma membrane was disrupted, and the cell contents were released, indicating necrosis. Gene expression studies revealed altered mitochondrial organization and dysfunction of the mitochondrial electron transfer chain due to the effects of enniatin $B$ on complex I function and assembly. We propose that EnnB acts by causing energy deprivation due to mitochondrial alteration in cells, leading to diverse outcomes in different cell types: a decrease in cell proliferation of cell lines vs. necrotic cell death in primary cells. This highlights the importance of recognizing the differences between cell lines and primary cells, especially when assessing the relevance of in vitro to in vivo findings.

\section{Conflict of interest}

The authors have declared no conflict of interest.

\section{Transparency document}

The Transparency document associated with this article can be found, in the online version.

\section{Acknowledgments}

This study was funded by the Academy of Finland (121724) (Application of modern molecular methods to investigate the mode of action of Fusarium avenaceum mycotoxins). Dr. Tiina Pessa-Morikawa is thanked for indispensable help with flow-cytometric studies.

\section{References}

Berdy, J., 1980. CRC Handbook of Antibiotic Compounds. Volume VI, Part 2, Peptolide and Macromolecular Antibiotics, Fusafungine. CRC Press, USA.

Bio-rad Real-Time PCR Applications Guide, 2006, Bio-Rad Laboratories, Inc., pp 41.

Breuer, M.E., Willems, P.H.G.M., Smeitink, J.A.M., Koopman, W.J.H., Nooteboom, M., 2013. Cellular and animal models for mitochondrial complex I deficiency: a focus on the NDUFS4 subunit. IUBMB Life 65, 202-208.

CODA-CERVA (Centrum voor Onderzoek in Diergeneeskunde en Agrochemie-Centre d'Étude et de Recherches Vétérinaires et Agrochimiques) 2011-2012. Carry-over of mycotoxins to animal products: a case study poultry. CODA-CERVA Scientific Report, pp. 141-144. www.coda-cerva.be/images/pdf/CODA_CERVA_Scientific_Report_ 2011_2012.pdf.

Conesa, A., Götz, S., García-Gómez, J.M., Terol, J., Talón, M., Robles, M., 2005. Blast2GO: a universal tool for annotation, visualization and analysis in functional genomics research. Bioinformatics 21, 3674-3676.

Dai, M., Wang, P., Boyd, A.D., Kostov, G., Athey, B., Jones, E.G., Bunney, W.E., Myers, R.M., Speed, T.P., Akil, H., Watson, S., Meng, F., 2005. Evolving gene/transcript definitions significantly alter the interpretation of GeneChip data. Nucleic Acids Res. Nov 10; 33 (20), e175.

Desjardins, A.E., 2006. Fusarium Mycotoxins Chemistry, Genetics and Biology. The American Phytopathological Society, St.Paul, Minnesota, USA (ISBN 0-89054-335-6). 
Devreese, M., De Baere, S., De Backer, P., Croubels, S., 2013. Quantitative determination of the Fusarium mycotoxins beauvericin, enniatin A, A1, B and B1 in pig plasma using high performance liquid chromatography-tandem mass spectrometry. Talanta 106 , 212-219.

Dornetshuber, R., Heffeter, P., Lemmens-Gruber, R., Elbling, L., Marko, D., Micksche, M., Berger, W., 2009a. Oxidative stress and DNA interactions are not involved in Enniatin- and Beauvericin-mediated apoptosis induction. Mol. Nutr. Food Res. 53, 1112-1122. http://dx.doi.org/10.1002/mnfr.200800571.

Dornetshuber, R., Heffeter, P., Sulyok, M., Schumacher, R., Chiba, P., Kopp, S., Koellensperger, G., Micksche, M., Lemmens-Gruber, R., Berger, W., 2009b. Interactions between $\mathrm{ABC}$-transport proteins and the secondary Fusarium metabolites enniatin and beauvericin. Mol. Nutr. Food Res 53, 904-920. http://dx.doi.org/10. 1002/mnfr.200800384.

Dornetshuber-Fleiss, R., Heilos, D., Mohr, T., Richter, L., Süssmuth, R.D., Zlesak, M., Berger, W., 2014. The naturally born fusariotoxin Enniatin B and Sorafenib exert synergistic activity against cervical cancer in vitro and in vivo. Biochem. Pharmacol. 93 (3), 318-331. http://dx.doi.org/10.1016/j.bcp.2014.12.013.

Dubrez-Daloz, L., Dupoux, A., Cartier, J., 2008. More than just inhibitors of apoptosis proteins. Cell Cycle 7 (8), 1036-1046. http://dx.doi.org/10.4161/cc.7.8.5783.

EFSA Panel on Contaminants in the Food Chain (CONTAM), 2014. Scientific opinion on the risks to human and animal health related to the presence of beauvericin and enniatins in food and feed. EFSA J. 12 (8), 3802.

Elmore, S., 2007. Apoptosis: a review of programmed cell death. Toxicol. Pathol. 35 (4), 495-616. http://dx.doi.org/10.1080/01926230701320337.

Ficheux, A.S., Sibiril, Y., Parent-Massin, D., 2013. Effects of beauvericin, enniatin b and moniliformin on human dendritic cells and macrophages: an in vitro study. Toxicon 71, 1-10.

Gammelsrud, A., Solhaug, A., Dendelé, B., Sandberg, W.J., Ivanova, L., Kocbach Bølling, A., Lagadic-Gossmann, D., Refsnes, M., Becher, R., Eriksen, G., Holme, J.A., 2012. Enniatin B-induced cell death and inflammatory responses in RAW 267.4 murine macrophages. Toxicol. Appl. Pharmacol. 261, 74-87.

Garrett, R.H., Grisham, C.M., 1999. 2nd Edition. Chapter 21, pp 598-611, Biochemistry. ( 2010 Brooks /Cole, Cengage Learning, 20 Channel Center Street. USA, Boston (ISBN10: 0030223180).

GeneCards, The Human Gene Database, 2015. www.genecards.org.

Irizarry, R., Bolstad, B., Collin, F., Cope, L., Hobbs, B., Speed, T., 2003. Summaries of Affymetrix GeneChip probe level data. Nucleic Acids Res. Feb 15; 31 (4), e15.

Ivanov, V.T., Evstratov, A.V., Sumskaya, L.V., Melnik, E.I., Chumburidze, T.S., Portnova, S.L., Balashova, T.A., Ovchinnikov, Y.A., 1973. Sandwich complexes as a functional form of the enniatin ionophores. FEBS Lett. 36, 65-71.

Ivanova, L., Egge-Jacobsen, W.M., Solhaug, A., Thoen, E., Fæste, C.K., 2012. Lysosomes as a possible target of enniatin B-induced toxicity in Caco-2 cells. Chem. Res. Toxicol. 25 (8), 1662-1674. http://dx.doi.org/10.1021/tx300114x.

Ivanova, L., Fæste, C., Delezie, E., Van Pamel, E., Daeseleire, E., Callebaut, A., Uhlig, S., 2014. Presence of enniatin B and its hepatic metabolites in plasma and liver samples from broilers and eggs from laying hens. World Mycotoxin J. 7 (29), 167-175. http://dx. doi.org/10.3920/WMJ2013.1609.

Jestoi, M., Rokka, M., Yli-Mattila, T., Parikka, P., Rizzo, A., Peltonen, K., 2004. Presence and concentrations of the Fusarium-related mycotoxins beauvericin, enniatins and moniliformin in finnish grain samples. Food Addit. Contam. 21, 794-802.

Jestoi, M., 2005. Emerging Fusarium - Mycotoxins in Finland Academic Dissertation, University of Turku. (ISBN 952-5568-03-2).

Jestoi, M., Rokka, M., Järvenpää, E., Peltonen, K., 2009. Determination of Fusarium mycotoxins beauvericin and enniatins (A, A1, B, B1) in eggs of laying hens using liquid chromatography-tandem mass spectrometry (LC-MS/MS). Food Chem. 115, 1120-1127.

Kamyar, M., Rawnduzi, P., Studenik, C.R., Kouri, K., Lemmens-Gruber, R., 2004. Investigation of the electrophysiological properties of enniatins. Arch. Biochem. Biophys. 429, 215-223.

Lewin, B., 2000. Genes VII, pp. 835-871. Oxford University Press, USA. (ISBN 0-19879277-8).
Liu, J., Lin, A., 2005. Role of JNK activation in apoptosis: a double-edged sword. Cell Res. 15, 36-42. http://dx.doi.org/10.1038/sj.cr.7290262.

Manyes, L., Escriva, L., Serrano, A., Rodríguez-Carrasco, Y., Tolosa, J., Meca, G., Font, G. 2014. A preliminary study in Wistar rats with enniatin A contaminated feed. Toxicol. Mech. Methods 24 (3), 179-190. http://dx.doi.org/10.3109/15376516.2013.876135.

Mereish, K.A., Solow, R., Bunner, D.L., Fajer, A.B., 1990. 1990 Sep-Oct;3(5):233-7. Interaction of cyclic peptides and depsipeptides with calmodulin. Pept. Res. Sep-Oct;3 (5) 233-237 (PMID: 1724618).

Neustadt, J., Pieczenik, S.R., 2008. Medication-induced mitochondrial damage and disease. Mol. Nutr. Food Res. 52 (7), 780-788. http://dx.doi.org/10.1002/mnfr.200700075.

Ovchinnikov, Y.A., Ivanov, V.T., Evstratov, A.V., Mikhaleva, I.I., Bystrov, V.F., Portnova, S.L. Balashova, T.A., Meshcheryakova, E.N., Tulchinsky, V.M., The enniatin ionophores. Conformation and ion binding properties. Int. J. Pept. Protein Res., . DOI: http://dx. doi.org/10.1111/j.1399-3011.1974.tb02407.x, (Article first published online: 12 JAN 2009), 1974.

Petruzzella, V., Vergari, R., Puzziferri, I., Boffoli, D., Lamantea, E., Zeviani, M., Papa, S., 2001 A nonsense mutation in the NDUFS4 gene encoding the $18 \mathrm{kDa}$ (AQDQ) subunit of complex I abolishes assembly and activity of the complex in a patient with Leighlike syndrome. Hum. Mol. Genet. 10 (5), 529. http://dx.doi.org/10.1093/hmg/10.5. 529.

Rhoades, R., Bell, D., 2009. Medical Physiology: Principles for Clinical Medicine. Williams \& Wilkins IV, p. 422 (ISBN-10: 1609134273).

Ritz, C., Streibig, J.C., 2005. Bioassay Analysis using R. J. Statist. Software Vol12, Issue 5.

Saeed, A.I., Sharov, V., White, J., Li, J., Liang, W., Bhagabati, N., Braisted, J., Klapa, M., Currier, T., Thiagarajan, M., Sturn, A., Snuffin, M., Rezantsev, A., Popov, D., Ryltsov, A., Kostukovich, E., Borisovsky, I., Liu, Z., Vinsavich, A., Trush, V., Quackenbush, J., 2003. TM4: a free, open-source system for microarray data management and analysis. Biotechniques Feb 34 (2), 374-378.

Smyth, G.K., 2004. Linear models and empirical bayes methods for assessing expression in microarray experiments. Stat. Appl. Genet. Mol. Biol. 3; article 3 (Epub 2004 Feb12).

Storey, J.D., Tibshirani, R., 2003. Statistical significance for genomewide studies. Proc Natl Acad Sci USA Aug 5100 (16), 9440-9445.

The EBI, Biological process, Mitochondrion Organization GO:0007005, 2015. https:// www.ebi.ac.uk, The European Bioinformatics Institute. http://www.ebi.ac.uk/ QuickGO/GTerm?id=GO:0007005.

The NCBI, 2015. TIMM8B translocase of inner mitochondrial membrane 8 homolog B (yeast) [Homo sapiens (human)], Gene ID: 26521. The National Center for Biotechnology Information (NCBI) Reference Sequence (RefSeq) database,(updated on 4-Oct2015) www.ncbi.nlm.nih.gov/gene/26521.

Tomoda, H., Huang, X.H., Cao, J., Nishida, H., Nagao, R., Okuda, S., Tanaka, H., Omura, S., Arai, H., Inoue, K., 1992. Inhibition of acyl-CoA: cholesterol acyltransferase activity by cyclodepsipeptide antibiotics. J Antibiot (Tokyo) Oct; 45 (10), 1626-1632 (PMID: 1473990)

Tonshin, A.A., Teplova, V.V., Andersson, M.A., Salkinoja-Salonen, M.S., 2010. The Fusarium mycotoxins enniatins and beauvericin cause mitochondrial dysfunction by affecting the mitochondrial volume regulation, oxidative phosphorylation and ion homeostasis. Toxicology 276, 49-57.

Uhlig, S., Torp, M., Heier, B.T., 2006. Beauvericin and enniatins A, A1, B and B1 in Norwegian grain: a survey. Food Chem. 94, 193-201.

Wätjen, W., Debbab, A., Hohlfeld, A., Chovolou, Y., Kampkötter, A., Edrada, R.A., Ebel, R. Hakiki, A., Mosaddak, M., Totzke, F., Kubbutat, M.H., Proksch, P., 2009. Enniatins A1, $\mathrm{B}$ and B1 from an endophytic strain of Fusarium tricinctum induce apoptotic cell death in H4IIE hepatoma cells accompanied by inhibition of ERK phosphorylation. Mol. Nutr. Food Res. Apr; 53 (4), 431-440. http://dx.doi.org/10.1002/mnfr. 200700428.

Wilson, E., 2003. Isozymes of mammalian hexokinase: structure, subcellular localization and metabolic function. J. Exp. Biol. 206, 2049-2057. http://dx.doi.org/10.1242/jeb. 00241. 